\title{
Bioactive Natural Products from Plants and Biotechnological Approaches for their Production
}

\author{
Niraj Tripathi, Swapnil Sapre, Iti Gontia-Mishra, Vijay Prakash and Sharad Tiwari
}

Biotechnology Centre, Jawaharlal Nehru Agricultural University, Jabalpur 482004, India

\begin{abstract}
Bioactive natural products are economically important as drugs, fragrances, pigments, food additives and pesticides. The biotechnological tools are important to select, multiply, improve and analyze medicinal plants for production of such products. The utilization of medicinal plant cells for the production of natural or recombinant compounds of commercial interest has gained increasing attention over the past decades. Plant tissue culture systems are possible source of valuable medicinal compounds, fragrances and colorants, which cannot be produced by microbial cells or chemical synthesis. In vitro production of bioactive natural products in plant cell suspension culture has been reported from various medicinal plants and bioreactors are the key step towards commercial production. Genetic transformation is a powerful tool for enhancing the productivity of novel products; especially by Agrobacterium tumefacians. Combinatorial biosynthesis is another approach in the generation of novel natural products and for the production of rare and expensive natural products. Recent advances in the molecular biology, enzymology and bioreactor technology of plant cell culture suggest that these systems may become a viable source of important secondary metabolites. Genetic fingerprinting could be a powerful tool in the field of medicinal plants to be used for correct germplasm identification. In addition, when linked to emerging tools such as metabolomics and proteomics, providing fingerprints of the plant's metabolites or protein composition, it gives data on phenotypic variation, caused by growth conditions or environmental factors, and also yield data on the genes involved in the biosynthesis. DNA profiling techniques like DNA microarrays serve as suitable high throughput tools for the simultaneous analysis of multiple genes and analysis of gene expression that becomes necessary for providing clues about regulatory mechanisms, biochemical pathways and broader cellular functions. New and powerful tools in functional genomics can be used in combination with metabolomics to elucidate biosynthetic pathways of natural products.
\end{abstract}

Keywords: Natural Products, Biosynthetic Pathway, Cell Culture, RNAi, Transcriptomics.

\section{INTRODUCTION}

Medicinal plants are the most exclusive source of life saving drugs for the world's population. The traditional medicine involves the use of different plant extracts or the bioactive constituents [1]. Several of these metabolites prevent chronic diseases and can be used as colorants, flavours, and as antimicrobials [2]. The bioactive natural products modify the functioning of the central nervous system (CNS) [3, 4]. The utilization of plant cells for the production of natural or recombinant compounds of commercial interest has gained increasing attention over the past decades [5]. Bioactive compounds currently extracted from plants are used as pharmaceuticals, agrochemicals, flavors and fragrance ingredients, food additives and pesticides. These products will never cease to play an important role in the search of novel therapeutic agents. Therefore, it is incontestable that works related to natural products continue to develop in many aspects involving researchers from various scientific backgrounds. In the search for alternatives for production of desirable medicinal compounds from plants, biotechnological approaches specifically plant tissue culture are found to have potential as a

*Address correspondence to this author at the Biotechnology Centre, Jawaharlal Nehru Agricultural University, Jabalpur 482004, India;

Tel/Fax: +917612681089; E-mail: shtiwari@gmail.com supplement to traditional agriculture in industrial production of bioactive plant metabolites [6].

Biotechnology in its broadest sense includes plant tissue culture, the use of molecular markers for breeding and fingerprinting purposes; molecular tools to study gene expression, as well as the use of all this information for genetic engineering of plants. Genetic fingerprinting could be a powerful tool in the field of medicinal plants, for precise germplasm identification. In addition, when linked to other emerging tools such as metabolomics and proteomics, it not only gives data on phenotypic variation caused by growth conditions or environmental factors, but also yields data on the genes involved in the biosynthesis [7]. The use of molecular markers in breeding is a well known technique for commodity crops such as the cereals, but has only a few reports on use of them for medicinal plants. For example in Cannabis, markers linked to high THC or CBD content was identified [8]. Similar work for other medicinal plants can be achieved in future, as genomic tools are becoming popular and easily accessible.

The present review elucidates different classes/subclasses of bioactive natural products along with an overview of their medicinal applications as antioxidants, anti-inflammatory agents, anti-allergic and anti-cancerous agents. The current information on 
applications of recent biotechnological tools in the production of bioactive natural compounds from plants has also been elucidated. The literature cited in the text on scientific developments, recent technological advances, and research trends evidently point out that bioactive natural products will be amongst the most significant resources of new formulations of drugs in the future.

\section{CLASSIFICATION OF BIOACTIVE NATURAL PRODUCTS}

Plants use secondary metabolites such as alkaloids, phenolics and terpenes for their defense against the herbivores. Bioactive natural products can be divided into different groups on the basis of their chemical properties.

\section{Terpenes}

Terpenes are the most diverse class of secondary compounds produced by plants. In addition to pest resistance, these compounds are also used as anticancer (taxol) and antimalarial (artemisinin) drugs. Different terpenes produced by plants as secondary metabolites are presumed to be involved in defense as toxins to a large number of plant feeding insects and mammals. Herein several examples are discussed from the 5 major subclasses of terpenes.

a. Monoterpenes (C10): Many derivatives are important agents toxic to insects. The pyrethroid (monoterpenes esters) occur in the leaves and flowers of Chrysanthemum species which shows strong insecticidal response (neurotoxin) to insects like beetle, wasps, moths, bees, etc. and a popular ingredient in commercial insecticides because of low persistence in the environment and low mammalian toxicity. In Pine and Fir, monoterpenes accumulate in resin ducts of the needles, twigs and trunks mainly as $\alpha$-pinene, $\beta$ pinene, limonene and myrecene which are toxic to numerous insects including bark beetles, a serious pest of conifer species [9].

b. Sesquiterpenes (C15): A number of sesquiterpenes have been reported for their role in plant defense. Abscisic acid (ABA) is also a sesquiterpene, plays vital regulatory roles in the initiation and maintenance of seed and bud dormancy and plants response to water stress by modifying the membrane properties [10].

c. Diterpenes (C20): Abietic acid is a diterpene found in pines and leguminous tress. It is present in or along with resins in resin canals of the tree trunk. Another compound phorbol (diterpene ester), found in plants of Euphorbiaceae and work as skin irritants and internal toxins to mammals. Furthermore, gibberellins, a group of plant hormones are also diterpenes which play various detrimental roles in numerous plant developmental processes such as seed germination, leaf expansion, flower and fruit set, dry weight and biomass production [11], stomatal conductance, $\mathrm{CO}_{2}$ fixation, phloem loading and assimilate translocation [12].

d. Triterpenes (C30): Several steroid alcohols (sterols) are important component of plant cell membranes, especially in the plasma membrane as regulatory channels and maintain permeability to small molecule by decreasing the motion of fatty acid chains. A triterpene, liminoid, a group of bitter substances in citrus fruits which act as antiherbivore compounds in members of family Rutaceae and some other families. Similarly, azadirachtin, a complex limnoid from Azadirachta indica, act as a feeding deterrent to some insects and exerts various toxic effects [13].

e. Polyterpenens (C5)n: Several high molecular weight polyterpenes occur in plants. Larger terpenes include the tetraterpenes and the polyterpenes as rubber provides protective mechanism for wound healing and defense against herbivores [14].

\section{Phenolics}

Plants produce a large variety of secondary products that contain an aromatic ring called phenol. They could be an important part of the plants defense system against pests and disease including root parasitic nematodes [15]. Elevated ozone (mean $32.4 \mathrm{ppb}$ ) increased the total phenolic content of leaves and had minor effects on the concentration of individual compounds [16].

a. Coumarin: They are simple phenolic compounds widespread in vascular plants and appear to function in different capacities in various plant defence mechanisms against insect herbivores and fungi. They are derived from the shikimic acid pathway which is found in bacteria, fungi and plants but absent in animals. They are a highly active group of molecules with a wide 
range of anti-microbial activity against both fungi and bacteria [17]. It is believed that these cyclic compounds behave as natural pesticidal defence compounds for plants. It is known that, 7hyroxylated simple coumarins may play a defensive role against parasitism of Orobanche cernua, by preventing germination, penetration and connection to the host vascular system [18]. Some coumarin derivatives have higher antifungal activity against large number of soil borne plant pathogenic fungi and exhibit more stability as compared to the original coumarin compounds [17].

b. Furanocoumarin or Furocoumarins: This phytotoxic substance is abundantly found in members of the family Umbelliferae including celery parsnip and parsley. These compounds are nontoxic until they are activated by light (UV-A). Psoralen, basic linear furocoumarin are known for its use in the treatment of fungal defence [19].

c. Lignin: It is a highly branched polymer of phenylpropanoid groups, formed from three different alcohols viz., coniferyl, coumaryl and sinapyl which are oxidized to free radical (ROS) by a ubiquitous plant enzyme peroxidises reacts simultaneously and randomly to form lignin [20]. Its chemical durability makes it relatively indigestible to herbivorous and insects pathogens. Lignification blocks the growth of the pathogen [21].

i. Flavonoids: Flavonoids are one of the largest classes of plant phenolic; perform different functions in plant system including pigmentation and defence [22]. Two other major groups of flavonoids found in flowers are flavanones and flavanols. They function to protect cell from UV-B radiation because of their accumulation in epidermal layers of leaves and stems and absorb light strongly in the UV-B region while letting visible (PAR) wavelengths throughout uninterrupted [23]. In addition, exposure of plants to increased UV$B$ light has been demonstrated to increase the synthesis of flavanones and flavanols suggesting that flavonoids may offer protection by screening out harmful UV-B radiation [16].

ii. Isoflavonoids: Isoflavonoids are derived from a flavanones intermediate, naringenin, ubiquitously present in plants and play a critical role in plant development and defence responses. They are secreted by the legumes and play a vital role in promoting the formation of nitrogen fixing nodules by symbiotic rhizobia [24]. Moreover, it seems that synthesis of these flavonoids is an effective strategy against reactive oxygen species [25] (ROS). The analysis of antioxidant enzymes like SOD, CAT, POX, APX, GPX and GR suggest that peroxidases are the most active enzymes in red cabbage seedlings exposed to $\mathrm{Cu}^{++}$stress. Isoflavonoids work as substrate for different peroxidases which are the first lines of defence against various environmental stresses like metal stress $[25,26]$.

iii. Tannins: Tannins are general toxins that significantly reduce the growth and survival of many herbivores and also act as feeding repellents to a great diversity of animals. Mammals such as cattle, beer and apes, characteristically avoid plant with high tannins contents [27]. Tannins have a special function in disease resistance of certain plants. They are known to prevent smudge in onions, a disease caused by fungus Colletotrichum circinans, in addition prevent spore germination and growth of other fungi [28].

\section{Sulphur Containing Natural Products}

They include GSH, GSL, phytoalexins, thionins, defensins and allinin which have been linked directly or indirectly with the defence of plants against microbial pathogens and a number of them thought to play role in the Systemic induced Resistance.

a. GSH: It is one of the major forms of organic sulphur in the soluble fraction of plants and has an important role as a mobile tool of reduced sulphur in the regulation of plant growth and development as well as cellular antioxidants in stress responses [29]. Specialized cell such as trichomes exhibit high activities of enzymes for synthesis of GSH and other phytochelatins necessary for detoxification of heavy metals [30, 31]. The GSH content varies between 3 to 10 $\mathrm{mM}$ and is present in the major cellular compartment of plant. In oxidative stress, GSH functions as direct antioxidants and also as a reducing agent for other antioxidants such as 
ascorbic acid [32]. It also works as integral weapons in the defence against ROS generated by ozone [33]. GSH is rapidly accumulated after fungal attack, acting as systemic messenger carrying information concerning the attack to non-infested tissues [34].

b. GSL: A group of low molecular mass $\mathrm{N}$ (nitrogen) and $S$ (sulphur) containing plant glucosides which are produced by higher plants in order to increase their resistance against the unfavourable effects of predators, competitors and parasites [35]. Mustard oil glucosides in crucifer and allyl cys sulfoxides in alum are examples of GSL [36]. The smelling volatiles forms from GSL catalyzed by myrosinase, cleaves glucose from its bond with the $S$ atom, resulting in glycon rearranges with loss of the sulphate to give pungent and chemically reactive products, function in defence as herbivorous toxins and feeding repellents [37]. The potency of GSL comes in picture when it is in contact with the plant enzyme myrosinase removes the $\beta$ glucose moiety leading to formation of an unstable intermediates i.e. isothiocyanates ( $R$ $\mathrm{N}=\mathrm{C}=\mathrm{S}$ ) and nitriles which function in defence as herbivore toxins and feeding repellents [38]. They affect the activity of enzymes involved in the antioxidant defence system and cell protection against DNA damage [39].

c. Phytoalexins: Phytoalexins are synthesized in response to bacterial or fungal infection or other forms of stress that helps to limit the spread of the invading pathogens by accumulating around the site of infection. Many of these changes are linked to a rapid apoptotic response, resulting in death of one or a few invaded plant cells, known as the hypersensitive response (HR). Cruciferous crops are cultivated worldwide because they are rich sources of phytoalexins [40].

d. Defensins, thionins and lectins: They are S-rich non-storage plant proteins synthesize and accumulate after attack of pathogens [41]. These proteins inhibit the growth of a broad range of fungi [42]. Some defensins are antifungal or occasionally show anti-bacterial activity. Defensins genes are partly pathogen-inducible and others that are involved in resistance can be expressed constitutively [43]. Some plant species produce lectins as defensive protein that bind to carbohydrates or glycoproteins. After being ingested by herbivores, lectins bind to epithelial cell lining of the digestive tracts and interfere with nutrient absorption [44].

\section{Nitrogen Containing Natural Products}

They include alkaloids, cyanogenic glucosides and non-proteins amino acids. They are of considerable interest because of their role in the antiherbivore defense and toxicity to humans.

a. Alkaloids: $\mathrm{A}$ large family of $\mathrm{N}$ (nitrogen) containing secondary metabolites found in approximately $20 \%$ of the species of vascular plants, most frequently in the herbaceous dicot and relatively less in monocots and gymnosperms [45]. Most of the alkaloids are believed to function as defensive elements against predators, especially mammals because of their general toxicity [46].

b. Cyanogenic glucosides (cyanogenic: cyanide $\{\mathrm{HCN}\}$ producing): These are not themselves toxic but are readily broken down to give off volatile poisonous substance like $\mathrm{HCN}$ and volatile $\mathrm{H}_{2} \mathrm{~S}$. Lima bean (Phaseolus lunatus L.) is a model plant for the study of inducible indirect ant herbivore defences including the production of volatile organic compounds (VOCs). The cyanogenesis may be considered as a vital direct defensive trait affecting Lima bean's overall defences in nature [47].

\section{PRODUCTION OF BIOACTIVE NATURAL PRODUCTS USING TISSUE CULTURE TECHNOLOGY}

Research in the area of plant tissue culture technology has resulted in the production of many pharmaceutical substances for new therapeutics. Advances in the area of cell cultures for the production of medicinal compounds has made possible the production of a wide variety of pharmaceuticals like alkaloids, terpenoids, steroids, saponins, phenolics, flavonoids, and amino acids. Successful attempts to produce some of these valuable pharmaceuticals in relatively large quantities by cell cultures are mentioned in Table 1.

a. Taxol (plaxitaxol): The bark of the taxus tree (Taxus wallichiana) produces a complex diterpene alkaloid which is a potent anticancer agent because of its unique mode of action on 
Table 1: Secondary Metabolites from Plant Cell, Tissue and Organs Cultures

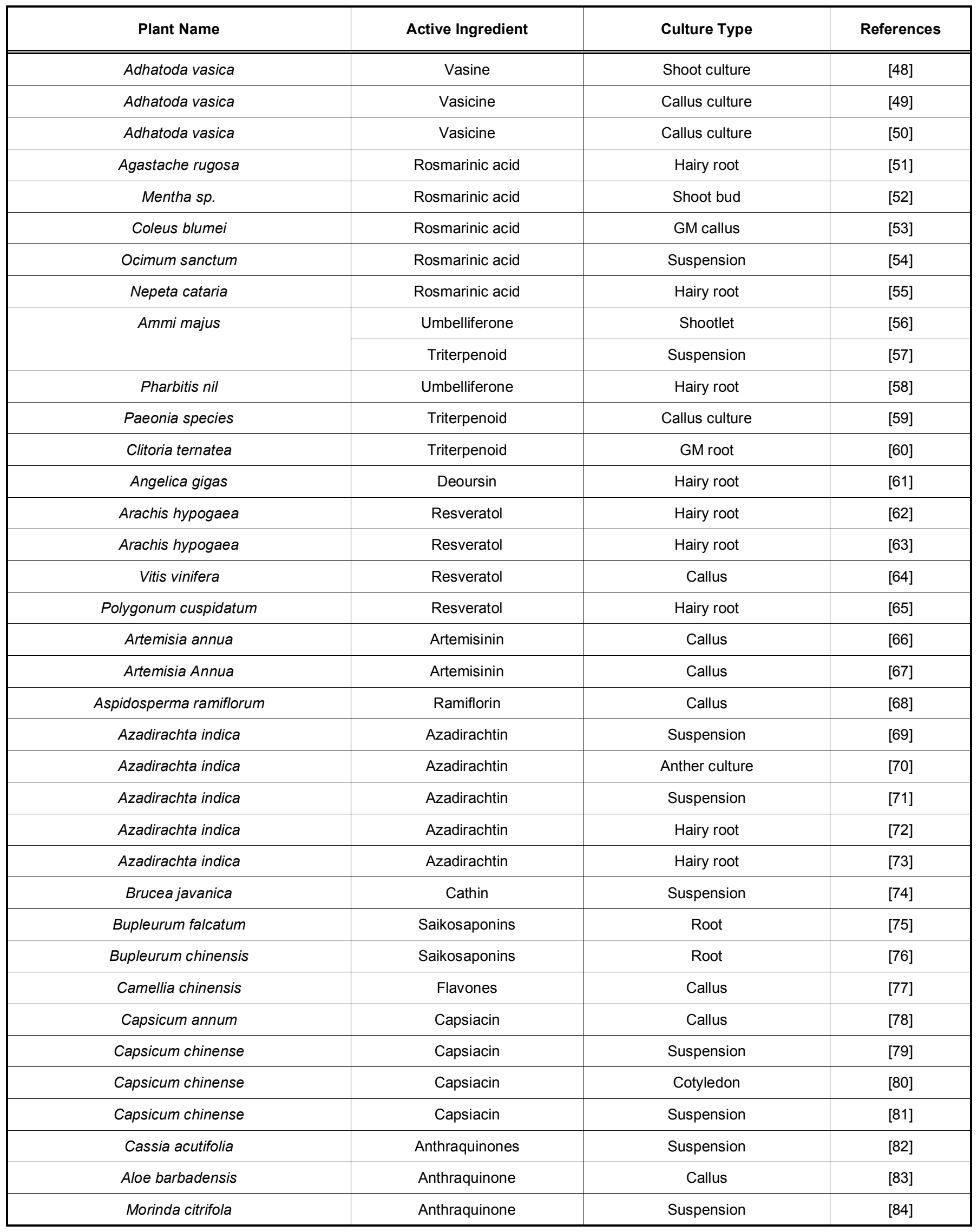


(Table 1). Continued.

\begin{tabular}{|c|c|c|c|}
\hline Plant Name & Active Ingredient & Culture Type & References \\
\hline Polygonum multiflorum & Anthraquinone & GM hairy roots & [85] \\
\hline Morinda citrifolia & Anthraquinone & Suspension & {$[86]$} \\
\hline \multirow[t]{8}{*}{ Catharanthus roseus } & Indole alkaloids & Suspension & {$[86]$} \\
\hline & Indole alkaloids & Callus & [87] \\
\hline & Vincristine & Suspension & [88] \\
\hline & Vincristine & Callus & [87] \\
\hline & Vincristine & Callus & [89] \\
\hline & Vincristine & Callus & {$[90]$} \\
\hline & Catharathine & Suspension & {$[91]$} \\
\hline & Catharathine & Callus & {$[87]$} \\
\hline Cayratia trifoliata & Stilbenes & Suspension & {$[92]$} \\
\hline \multirow[t]{2}{*}{ Centella asiatica } & \multirow[t]{2}{*}{ Asiaticoside } & Hairy root & [93] \\
\hline & & Callus & {$[94]$} \\
\hline Corydalis ambigua & Corydaline & Embryo & [95] \\
\hline Coscinium fenustratum & Berberine & Suspension & {$[96]$} \\
\hline Drosera rotundifolia & 7-Methyljuglone & Shoot culture & {$[97]$} \\
\hline Eleutherococcus senticosus & Eleuthrosides & Suspension & {$[98]$} \\
\hline Eriobotrya japonica & Triterpenes & Callus & {$[98]$} \\
\hline Fabiana imbricata & Rutin & Callus, suspenson & {$[99]$} \\
\hline Fagopyrum esculentum & Rutin & Hairy root & [100] \\
\hline Fritillaria unibracteata & Alkaloids & Multiple shoot & {$[101]$} \\
\hline Gentiana macrophylla & Glucoside & Hairy root & {$[102]$} \\
\hline Gentianella austriaca & Xanthone & Multiple shoot & {$[103]$} \\
\hline Glycyrrhiza glabra & Glycyrrhizin & Hairy root & [104] \\
\hline Gymnema sylvestre & Gymnemic acid & Callus & {$[105]$} \\
\hline Hemidesmus indicus & Lupeol, Rutin & Shoot culture & {$[106]$} \\
\hline Hypericum perforatum & Hypericin & Multiple shoot & {$[107]$} \\
\hline Mentha arvensis & Terpenoid & Shoot & {$[108]$} \\
\hline Momordica charantia & Flavonoid & Callus & {$[109]$} \\
\hline Taxus & Taxol & Elicitation & {$[110]$} \\
\hline Taxus & Taxol & Nodule culture & {$[110]$} \\
\hline Taxus & Taxol & Suspension & {$[112]$} \\
\hline Papaver & Morphine, codeine & Callus culture & {$[113]$} \\
\hline Papaver somniferum & Morphine, codeine & Hairy root culture & {$[114]$} \\
\hline D. zingiberensis & Diosgenin & Elicitation & {$[115]$} \\
\hline D. zingiberensis & Diosgenin & Elicitation & [116] \\
\hline
\end{tabular}


the micro tubular cell system. The production of taxol by various Taxus species is one of the most extensively explored areas of plant cell cultures in recent years owing to the enormous commercial values of taxol, the scarcity of the taxus trees and its costly synthesis process [117]. The estimated need of taxol per year is $250 \mathrm{~kg}$ of purified drug which requires approximately 750,000 trees. The ever increasing demand of Taxol in the treatment of cancer needs a large source of plants for extraction. Therefore, T. wallichiana is exposed to the risk of extinction [118]. To improve the productivity of taxol and related taxanes in cell cultures for commercial exploitation, efforts have been focused on assaying the biosynthetic activities of cultured cells. Approaches include optimizing cultural conditions, screening of high yielding cell lines, optimization of growth and production media, induction of secondary metabolite pathways by elicitors and precursors, using a two-phase culture system and immobilization techniques. For the first time, taxus cell cultures were used to produce taxol (paclitaxel) [119]. Paclitaxel was found to accumulate at high yields $(1.5 \mathrm{mg} / \mathrm{l})$ exclusively in the second phase of growth. A similar level of paclitaxel from Taxus brevifolia cell suspension cultures following 10 days in culture with optimized medium containing $6 \%$ fructose was established [120]. Addition of carbohydrate during the growth cycle increased the production rate of paclitaxel [121]. In addition to paclitaxel, several other toxoids have been identified in both cell and culture medium of taxus cultures [122]. In order to increase the toxoid production addition of phenylalanine to culture medium was found to assist in maximum taxol production by $T$. cuspidate [123]. The accumulation of paclitaxel and related taxanes in Taxus plants is thought to be a biological response to specific external stimuli and jasmonates have been reported to play an important role in signal transduction process which regulates defense genes in plants [124]. The influence of biotic and abiotic elicitors was also studied to improve the production and accumulation of taxol through tissue culture. The abiotic elicitors viz., vanadyl sulphate, silver nitrate, cobalt chloride, arachidonic acid, ammonium citrate and salicylic acid have been used to improve taxane production in $T$. baccata cell cultures. Biotic elicitor like Rhizopus stolonifer fungus (25 mg/L) used in combination with the abiotic elicitors methyl jasmonate $(10 \mathrm{mg} / \mathrm{L})$ and salicylic acid (100 mg/L) increased taxol production by 16folds upon addition on day 25-30 of culture medium [110]. Factors influencing stability and recovery of paclitaxel from suspension cultures and the media have been studied in detail and effects of rare earth elements and gas concentrations on taxol production have been reported [112].

b. Morphine and codeine: Opium poppy is the only plant known to produce the narcotic analgesics codeine and morphine, which accumulate at copious levels in specialized laticifers that accompany sieve elements of the phloem in all organs. The ability to synthesize a specialized metabolite, such as morphine, depends on the evolution of several biosynthetic enzymes via the recruitment of genes arising through duplication events in the genome [125]. Papaver bracteatum (Iranian poppy) is considered as an alternative to $P$. somniferum for the production of benzylisoquinoline alkaloids due to its high thebaine content. Thebaine is a precursor of codeine which is converted to codeine and simultaneously to morphine. Because of the low activity of enzymes involved in demethylation of codeine and morphine, the yields of codeine and morphine is low in Papaver bracteatum [126]. Latex from the opium poppy ( $P$. somniferum) is a commercial source of the analgesics, morphine and codeine. Callus and suspension cultures of $P$. somniferum were investigated as an alternative means for production of these compounds. Production of morphine and codeine in morphologically undifferentiated culture has been reported [113]. Culture media without exogenous supplementation of hormones, showed to three times higher yield of codeine and morphine concentrations as compared to culture medium supplied with hormones. The conversion yield was $70.4 \%$ and $88 \%$ of the codeine converted was excreted into the medium [127]. Hairy roots resemble normal roots in terms of differentiated morphology and biosynthetic machinery, producing similar secondary metabolites compared to wild-type roots. As a result, hairy roots have been a topic of intense research for the past three decades, fueling innumerable attempts to develop in vitro 
hairy root cultures for a large number of plants for the commercial-scale production of secondary metabolites [128]

c. Ginsenosides: The root of Panax ginseng C.A. Mayer, so-called ginseng, has been widely used as a tonic and highly prized medicine since ancient times [129]. It is known for its numerous properties such as antioxidant, blood circulation promoter, anti-diabetic agent, pain relief treatment, anti-cancer drug and immune system stimulant. It is also been recognized as a miraculous promoter of health and longevity. The primary bioactive constituents of ginseng were identified as ginsenosides, a group of triterpenoid saponins. Among them, ginsenoside $\mathrm{Rg} 1$ is most important active molecule reported from Panax ginseng. Stirred tank fermentation process is considered as an important landmark in the commercialization of plant tissue and cell culture on a large scale. A. tumefaciens infected root cultures were found to be more effective as compared to normal root cultures for the production of ginsenosides [130]. Other types of tissue cultures, such as embryonic tissues and hairy roots transformed by Agrobacteria have been examined [131]. These developments indicate that ginseng cell culture process is still an attractive area for commercial development around the world and it possesses great potential for mass industrialization [132]. Concentration of plant growth regulators in the medium influences the cell growth and ginsenoside production in the suspension cultures [125]. Studies have shown that addition of methyl jasmonate or methyl dihydrojasmonate to suspension cultures increases the production of ginsenosides [134]. Jasmonic acid also improves the accumulation of ginsenosides in the root cultures of ginseng.

d. L-DOPA: L-3,4-dihydroxyphenylalanine is an important intermediate of secondary metabolism in higher plants and precursor for alkaloids, betalain, and melanine isolated from Vicia faba, Mucuna pruriens, Baptisia tinctoria and Lupinus albus [129]. It is also precursor for catecholamines in animals and is being used as a potent drug for Parkinson's disease, a progressive disabling disorder associated with a deficiency of dopamine in brain [135]. The widespread application of this therapy created a demand for large quantities of L-DOPA at an economical prices and leading to the introduction of cell cultures as an alternative means for enriched production. The highest concentration of DOPA was obtained from Mucuna hassjoo cells cultivated in MS medium fortified with 0.025 $\mathrm{mg} / \mathrm{l} 2,4-\mathrm{D}$ and $10 \mathrm{mg} / \mathrm{l}$ kinetin. The level of DOPA in the cells was about $80 \mathrm{mmol} / \mathrm{g}-\mathrm{fw}$ [136].

e. Berberine: It is an isoquinoline alkaloid found in the roots of Coptis japonica and cortex of Phellondendron amurense. This antibacterial alkaloid has been identified from the cell cultures of Coptis japonica, Thalictrum spp. and Berberis spp [137]. The productivity of berberine was increased in cell cultures by optimizing the nutrients in the growth medium and concentration of phytohormones. Other methods for increasing yields include elicitation of cultures with a yeast polysaccharide elicitor [132].

f. Diosgenin: It is a precursor for the chemical synthesis of steroidal drugs and is immensely important for pharmaceutical industries [138]. The perennial medicinal herb Dioscorea zingiberensis is a very important plant used for steroid drug manufacturing due to high levels of diosgenin in rhizome. Diosgenin mainly exists in plant cells in the form of the ligand of saponin, with its C3 and C26 linked to sugar chains via saponin bonds. Saponins exist in the cells which are wrapped tightly by large amounts of lignocellulose and starch [139]. Several attempts have been made for diosgenin production from cell cultures [132]. The search for high-producing cell lines coupled to recent developments in immobilized cultures and the use of extraction procedures, which convert furostanol saponins to spirostanes such as diosgenin, will be useful in increasing productivity in future [132]. Diarra et al. studied the effect of ethylene on diosgenin biosynthesis in in vitro cultures of $D$. zingiberensis [115]. The diosgenin biosynthesis was significantly promoted when samples were treated with ethylene at concentration E3 (104 dilution of $40 \%$ ethephon), in contrast to control samples. Treatment with high concentrations of ethylene had inhibitory effect, whereas with low concentration of the gas elicitor brought about no detectable deleterious effect on growth rate and diosgenin content of the cultures. Effects of three polysaccharides namely exopolysaccharide (EPS), water-extracted mycelial polysaccharide (WPS) and sodium hydroxide-extracted mycelial 
polysaccharide (SPS) with their corresponding oligosaccharides have been investigated on growth and diosgenin accumulation in cell and seedling cultures of $D$. zingiberensis [116].

g. Capsaicin: An alkaloid, used mainly as a pungent food additive in formulated foods [140]. It is obtained from fruits of green pepper (Capsicum sp.). Capsaicin is also used in pharmaceutical preparations as a digestive stimulant and for rheumatic disorders [141]. Suspension cultures of $C$. frutescens produce low levels of capsaicin, but immobilizing the cells in reticulated polyurethane foam can increase production approximately 100-fold. Further improvements in productivity can be brought about by supplying precursors such as isocapric acid. A biotechnological process has been developed for the production of capsaicin from C. frutescens cells. Ravishankar and Rao have studied the effects of nutritional stress on capsaicin production in immobilized cell cultures of C. annum [142]. Biotransformation of externally fed protocatechuic aldehyde and caffeic acid to capsaicin in freely suspended cells and immobilized cells cultures of $C$. frutescenshas also been reported [143]. Manipulation of culture strategies were adopted to study the influence of nutrient stress, $\mathrm{pH}$ stress and precursor feeding on the biosynthesis of capsaicin in suspension and immobilized cell cultures of $C$. chinense [80]. Cells cultured in the absence of one of the four nutrients (ammonium and potassium nitrate for nitrate and potassium stress, potassium dihydrogen orthophosphate for phosphorus stress, and sucrose for sugar stress) influenced the accumulation of capsaicin. Among the stress factors studied, nitrate stress showed maximal capsaicin production on day 20 (505.9 \pm $2.8 \mu \mathrm{g} \mathrm{g}^{-1} \mathrm{fw}$ ) in immobilized cell, whereas in suspension cultures the maximum accumulation $\left(345.5 \pm 2.9 \mu \mathrm{g} \cdot \mathrm{g}^{-1} \mathrm{fw}\right)$ was obtained on tenth day. Different $\mathrm{pH}$ affected capsaicin accumulation; enhanced capsaicin production $\left(261.6 \pm 3.4 \mu \mathrm{g} \cdot \mathrm{g}^{-1} \mathrm{fw}\right)$ was observed in suspension cultures at $\mathrm{pH} 6$ on day 15 , whereas in case of immobilized cultures the highest capsaicin content $\left(433.3 \pm 3.3 \mu \mathrm{g} \mathrm{g}^{-1} \mathrm{fw}\right)$ was obtained at $\mathrm{pH} 5$ on $10^{\text {th }}$ day. Addition of capsaicin precursors and intermediates significantly enhanced the biosynthesis of capsaicin, incorporation of vanillin at $100 \mu \mathrm{M}$ in both suspension and immobilized cell cultures resulted in maximum capsaicin content with $499.1 \pm 5.5{\mu g ~ g^{-1}} \mathrm{fw}$ on day 20 and 1,315.3 \pm 10 $\mu \mathrm{g} \mathrm{g}^{-1} \mathrm{fw}$ on day 10 , respectively. Among different culture strategies followed to enhance capsaicin biosynthesis in cell cultures of $C$. chinense, cells fed with vanillin resulted in the maximum capsaicin accumulation. The rate of capsaicin production was significantly higher in immobilized cells as compared to suspension cell cultures [80].

h. Camptothecin: It is an effective antitumor alkaloid isolated from Camptotheca acuminate [144]. 10-hydroxycamptothecin, a promising derivative of camptothecin is under clinical trials in US. Secondary metabolite accumulation and nitric oxide (NO) generation are two common responses of plant cells to fungal elicitors and NO has been reported to play important roles in elicitor-induced secondary metabolite production. However, the source of elicitor-triggered NO generation in plant cells remains largely unknown. PB90-induced NO generation is at least partially dependent on NR and NRmediated NO signaling is essential for fungal elicitor-induced camptothecin production of $C$. acuminata cells [145].

i. Vinblastine and Vincristine: The dimeric indole alkaloids vincristine and vinblastine are valuable drugs in cancer chemotherapy due to their potent antitumor activity against various leukemia and solid tumors. These compounds are extracted commercially from large quantities of Catharanthus roseus. Since the intact plant contains low concentrations $(0.0005 \%)$, plant cell cultures have been employed as an alternative to produce large amounts of these alkaloids [146]. Vinblastine is composed of catharanthine and vindoline. Vindoline is more abundantly present in plants than catharanthine, it is less expensive [147]. A crude preparation of $70 \%$ ammonium sulphate precipitated protein form the cultured cells of $C$. roseus were used as an enzyme source. The reaction mixture contained catharanthine, vindoline, Tris buffer, $\mathrm{pH} 7.0$, and the crude enzyme; the mixture was incubated at $3000 \mathrm{C}$ and for $3 \mathrm{~h}$. The products of the reaction were various dimeric alkaloids including vinamidine, 3(R)-hydroxyvinamidine, and 3,4anhydrovinblastine. Dimerization using ferric ion catalyst in the absence of enzyme resulted in 
anhydrovinblastine and vinblastine in $52.8 \%$ and $12.3 \%$ yield, respectively. The yield of vinblastine via chemical coupling was improved in the presence of ferric chloride, oxalate, maleate, and sodium borohydride [148]. Influence of various parameters like stress, addition of bioregulators, elicitors and synthetic precursors on indole alkaloids production were studied in detail by Zhao et al. [149, 150]. Various elicitors of hydroxylase, peroxidase, acetyltransferase and inhibitors of oxygenase were added to a $C$. roseus cell culture medium to investigate the regulatory effects on tabersonine, vindoline and vinblastine biosynthesis. Hydrogen peroxide was found to be the most effective agent for enhancing the biosynthesis of tabersonine [151].

j. Podophyllotoxin: It is an antitumor aryltetralin lignin found in Podophyllum peltatum and $P$. hexandrum. It also serves as a starting material for the preparation of its semisynthetic derivatives, etoposide and teniposide, widely used in anti-tumor therapy [152]. These plants, which grow very slowly, are collected from the wild and are thus increasingly rare. This limits the supply of podophyllotoxin and necessitates the search for alternative production methods [127]. In a study, 3mM conifery1-alcohol complex yielded $0.013 \%$ podophyllotoxin on a dry weight basis, but the cultures without the precursor produced only $0.0035 \%$ [153].

\section{GENETIC TRANSFORMATION TO MANIPULATE THE QUALITY AND PRODUCTION OF BIOACTIVE NATURAL COMPOUNDS}

Genetic transformation of medicinal plants has been exploited using two major tools: $A$. rhizogenes, to produce hairy roots, either with a gene of interest or not [154], and secondly, A. tumefaciens to obtain stable transformants. This latter could be used for two purposes. The first one is to solve cultivation problems that these plants might encounter when domesticated. This can include, e.g., herbicide tolerance [155] or approaches to engineer pathogen resistance [156]. Secondly, genetics transformation is needed for metabolic engineering, as will be discussed more in detail in the next paragraph. Although, numerous reports have been published about genetic engineering of medicinal plants' to our knowledge not a stable genetically modified medicinal plant are known for cultivation, although field trials have been done with a transgenic poppy to evaluate pollen flow [157].
Direct manipulation of DNA sequences to alter gene expression in medicinal plants is an area that is ready for expansion provided a trait can be related to one or a small number of genes. The primary target for trait manipulation in medicinal plants is to increase the content of active compounds. In Mentha spp. (mint), biosynthetic pathways have been engineered to modify essential oil production. A wild tomato species Solanum habrochaites contains a typical terpene pathway in its chloroplast which allows these plants to produce exceptionally high concentrations of 7epizingiberene, a specific sesquiterpene with toxic and repellent properties against herbivores. This pathway is absent in cultivated tomatoes. The pathway of cultivated tomatoes was modified to produce 7epizingiberene by using both conventional breeding as well as metabolic engineering. These modified tomato plants produce higher levels of 7-epizingiberene as well as exhibited enhanced tolerance against several insect pests.

\section{RNA INTERFERENCE (RNAi) TECHNOLOGY TO ENHANCE THE PRODUCTION OF BIOACTIVE NATURAL COMPOUNDS}

RNA interference is the powerful tool of gene knockdown for enhancing secondary metabolite production from medicinal plants [158]. By degradation of only the mRNA associated to dsRNA also known as co-suppression or posttranscriptional gene silencing in plants [159]. This technology has been used to block the activity of codeinone reductase involved in the biosynthesis of morphinan alkaloid [160]. The knockdown activity of codeinone reductase through DNA-directed RNAi in transgenic opium poppy (Papaver somniferum) resulted in accumulation of precursor (s)-retculine at the expense of morphine, codeine, oripavine and thebaine [161] and also used to block the activity of berberine bridge enzyme (BBE) in California poppy [162]. The RNAi technology has become an important tool for accelerating the breeding of medicinal plants, where as conventional mutation breeding approach failed [161]. The RNA mediated suppression of tryptamine biosynthesis in C. roseus during hairy root culture eliminates production of monoterpene indole alkaloids, tryptamine and secologanin [163]. RNAi mediated gene-silencing challenges for bioactive products in medicinal plants are presented in Table $\mathbf{2}$.

\section{DNA MICROARRAY FOR EXPRESSION AND PROFILING OF BIOACTIVE NATURAL PRODUCTS}

DNA microarray was developed in response to the need for a high-throughput, efficient and 
Table 2: RNAi Mediated Gene-Silencing Challenges for Bioactive Products in Medicinal Plants

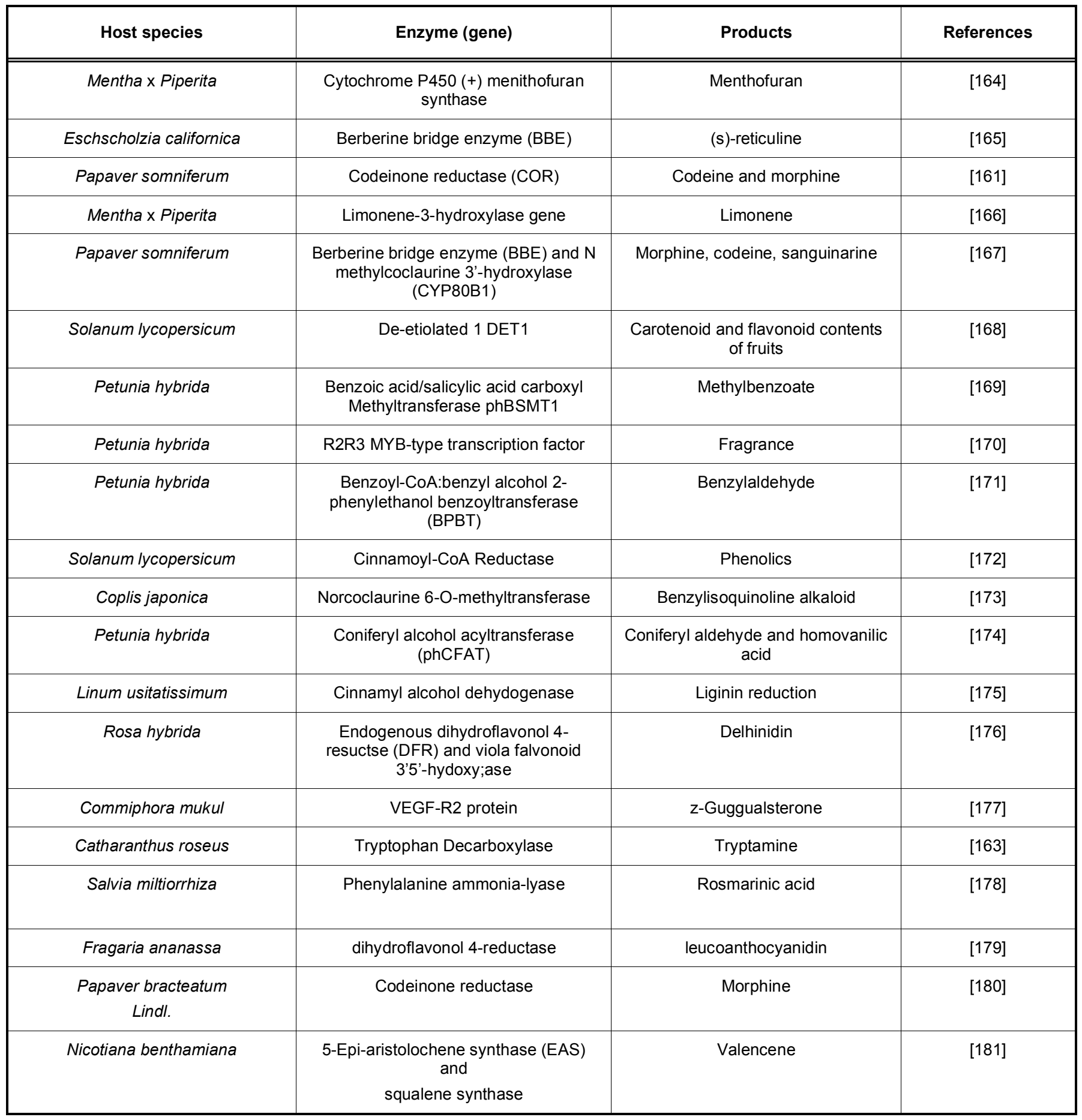

comprehensive strategy that can simultaneously measure all the genes or a large defined subset encoded by a genome [182]. DNA profiling techniques like DNA microarrays serve as suitable high throughput tools for the simultaneous analysis of multiple genes and analysis of gene expression that becomes necessary for providing clues about regulatory mechanism, biochemical pathways and broader cellular functions [183]. DNA microarray is mostly applied in pharmacogenomics to discover new analytical and predictive signs and biomarkers of therapeutic reaction, elucidation of molecular mechanism of action of an herb, its formulations or its phytochemical composition and herbal drug development. In pharmacogenomics, side-effects of herbs are studied to confer drug sensitivity or resistance of drugs. High-density DNA 
microarray has been used for the multiple gene expression effects exhibited by Ginkgo biloba leaf extract EGb 761 [184] which has notable neuromodulatory effects in vivo. In Centella asiatica, different genes have been identified and isolated to understand the bioactivity of Centella with clinical effectiveness at molecular level. Coptidis rhizoma is a medicinal herb has antiproliferative activity of berberine alkaloid and causes human pancreatic cancer cell lines [185]. The expression effects of antiproliferative active genes in berberine were showed by DNA microarray. Several Fritillaria species contain D2 and D3 regions in $26 \mathrm{~S}$ rDNA gene that has been printed on the polylysine coated slides using oligonucleotide polymorphic probes to prepare a DNA chip which is used for rapid and efficient genotyping and plants species authentication [186-187]. DNA microarray provides opportunity for studying herb-drug interactions and its mechanisms.

\section{FUNCTIONAL GENOMICS APPROACH FOR BIOACTIVE NATURAL PRODUCTS}

In principle, each natural product is formed by chemical transformations of small and larger molecules through a number of enzymatic reactions. To understand how a natural product is synthesized, the enzymes involved in these reactions need to be identified and the complex network of regulations and interactions is to be studied. This identification can be done on a gene and genome level, as discussed below. This might, however, have the advantage that it does not always give information on the nature of the encoded enzyme, that is, which reaction it is biochemically performing. Nevertheless, based on homology comparisons, often a function can be attributed to a newly discovered gene. Recently there is shift in gene studies, going from single-gene studies towards pathways and to whole-genome studies. New and powerful tools in functional genomics can thus be used in combination with metabolomics to elucidate biosynthetic pathways of natural products [146]. The basic question in this research field is to identify all the players involved in the biosynthesis of a natural product, both on the enzyme level and on the regulation level, so that the road is paved for metabolic engineering.

The general concept behind metabolic engineering is that certain pathways within a biosynthesis network could be stimulated or favoured over others, by overexpressing a crucial, for example rate-limiting, enzyme. In simple cases this approach has led to good results.
Upon over-expression of a squalene synthase gene a higher biosynthesis of triterpenes and phytosterols in Panax ginseng was found [146]. In food crops metabolic engineering has been done; one recent example includes the increase in the flavonoids and carotene content in tomato, obtained through RNAimediated suppression of the DET1 gene [168]. Overexpression of a transferase in tomato, involved in the synthesis of chlorogenic acid, has shown to give rise to accumulation of an antioxidant that protects against age-related degenerative diseases when supplied to animal diet [189]. Alternatively, silencing a gene giving rise to a specific enzyme in a side branch of a certain pathway, can also lead to accumulation of a certain metabolite [161]. Silencing the pathway leading to morphine in $P$. somniferum, with the positive side effect that reticuline and its methylated forms accumulated. Another nice example is the engineering of the monoterpene biosynthesis in mint $[164,167]$. Metabolic engineering can also be used to block the synthesis of unwanted metabolites. The manipulation of the caffeine content in coffee plants is such an example [190]. With this approach toxin production in medicinal plants could also be regulated.

cDNA-amplified fragment length polymorphism (cDNA-AFLP), has been the functional-genomics tool of choice to study gene expression profiles related to the biosynthesis of secondary metabolites. cDNA-AFLP has the advantage that it is an open tool, i.e., that no prior genomic data are needed [191, 192]. Indeed, for most medicinal plants limited or even no information is available on genomic sequences, nor do cDNA libraries exist that could be used as a template for micro-arrays. The principle of cDNA-AFLP is as follows: mRNA is extracted from the tissue of choice; the mRNA is converted to cDNA and digested with two restriction enzymes. Adapters are ligated after which this pool of fragments is used for a selective round of amplification. A high-resolution genome-wide profiling of transcripts can be visualized on acrylamide gels, which can then be analyzed using different software. Thus far, jasmonate-induced changes on the transcript and alkaloid profiles of tobacco BY-2 and Catharanthus roseus cell cultures have been monitored [193]. An inventory of hundreds of genes, potentially involved not only in alkaloid biosynthesis but also possibly in plant secondary metabolism in general, has been built. Thereafter, large-scale functional analysis of genes from this inventory, involved in plant secondary metabolism is performed. This includes the isolation of full-length open reading frames (FL-ORFs) and 
introduction and functional analysis of them in transgenic plant cells. Tools to improve and speed-up functional analysis of candidate genes in transgenic plant cells, such as medium-throughput strategies for isolation of FLORFs, super-transformation of plant cells with reporter gene constructs, transient protoplast expression assays and micro-array facilities, have been designed and their use validated.

\section{METABOLOMICS APPROACHES TO CONTROL THE PRODUCTION OF BIOACTIVE NATURAL COMPOUNDS}

The phenotype of an organism is the result of the combination of multiple intertwined, dynamic and linear/non-linear interactions among different elements (DNA, RNA, proteins and metabolites) with the environment (developmental stages and/or adverse conditions such as salinity, temperature and water or nutrient availability). For this reason, most genomescale studies require an accurate phenotype description besides the analysis of RNA transcripts, proteins and metabolites. Nevertheless, the sum of these three aspects does not provide a clear picture of the actual phenotype of a given organism but a sequential characterization of the elements one by one. This approach lacks the emerging properties that characterize biological organisms; therefore there is an increasing need for the integration of all these aspects. This is of especial relevance when the objective is to understand how plants respond to environmental cues. In this sense, whereas gene and protein expression represent the potential of plants to respond to adverse conditions, metabolites constitute the true integration of these two aspects plus the influence of the environment and/or other organisms. However, we first need to understand what information can be extracted from the application of the different profiling (omics) methodologies and how can metabolomics help to better comprehend the nature of phenotypes. The term metabolomics has been defined as the identification and quantitation of all low molecular weight metabolites in a given organism, at a given developmental stage and in a given organ, tissue or cell type. This is a challenging task due to the wide array of molecules with different structures and chemical properties. For instance, it is estimated that a single accession of Arabidopsis contains more than 5000 metabolites, most of them yet uncharacterized.

Metabolic engineering can also be used to block the synthesis of unwanted metabolites. With this approach toxin production in medicinal plants could also be regulated. Extracts of Ginkgo biloba, contain a toxic component, ginkgolic acid. For the final commercial product there usually is a norm for these toxic compounds, which are (partially) removed during the extraction, but if varieties could be engineered with low contents of these toxins, this would reduce production costs. Current developments in tissue culture technology indicate that transcription factors are efficient new molecular tools for plant metabolic engineering to increase the production of valuable compounds [194]. In vitro cell culture offers an intrinsic advantage for foreign protein synthesis in specific conditions since they can be designed to produce therapeutic proteins, including monoclonal antibodies, antigenic proteins that act as immunogens, human serum albumin, interferon, immuno-contraceptive protein, ribosome unactivator trichosantin, antihypertensive drug angiotensin, leu-enkephalin neuropeptide, and human hemoglobin [195]. The appeal of using natural products for medicinal purposes is increasing and metabolic engineering can alter the production of pharmaceuticals and help to design new therapies. At present, researchers aim to produce substances with antitumor, antiviral, hypoglycemic, anti-inflammatory, antiparasitic, antimicrobial, tranquilizer and immunomodulating activities through tissue culture technology.

Different genes responsible for scopolamine, nicotine and berberine biosynthesis have been cloned, making the metabolic engineering of these alkaloids feasible. Expression of two branching-point enzymes was engineered like putrescine $\mathrm{N}$-methyltransferase (PMT) in transgenic plants of Atropa belladonna and Nicotiana sylvestris and (S)-scoulerine 9-Omethyltransferase (SMT) in cultured cells of $C$. japonica and Eschscholzia californica. Overexpression of PMT increased the nicotine content in N. sylvestris, whereas suppression of endogenous PMT activity severely decreased the nicotine content and induced abnormal morphologies. Ectopic expression of SMT caused the accumulation of benzylisoquinoline alkaloids in $E$. californica [196].

\section{CONCLUSION}

Natural products have inspired many developments in drug discovery. There are many historical examples in which the natural product has not just been the medicinal product but has also helped to reveal a novel aspect of drug isolation. Because it is extremely timeconsuming and expensive to create extensive collections of isolated and structurally characterized 
natural products, it is still attractive to screen mixtures of compounds to isolate and identify the active lead, from the plant extracts and microbes. Plants are the best combinatorial chemists still providing hidden secrets of their healing properties to relieve humanity from fatal diseases. The existing knowledge of ethnic medicines has developed several leads in healthcare and drug discovery and also as a template for discovery. With the rapidity of modern industrialization, a lot of ethnic information used in healthcare is in danger of being lost. Hence, this is the need of the hour to develop and document traditional knowledge and medicine, which will further assist in developing suitable drugs for various ailments in the future. For drug discovery from natural products, innovative approaches include, use of genomics, techniques to mine previously untouched environments and screening technologies which to a large extent, need to be explored through national and international collaboration and cooperation. In vitro propagation of medicinal plants with enriched bioactive principles and cell culture methodologies for selective metabolite production has been found to be highly useful for commercial production of medicinally important compounds. The increased use of plant cell culture systems in recent years is perhaps due to an improved understanding of the secondary metabolite pathway in economically important plants. Advances in plant cell cultures could provide new means for the costeffective, commercial production of even rare or exotic plants, their cells, and the chemicals that they will produce. Knowledge of the biosynthetic pathways of desired compounds in plants as well as of cultures is still rudimentary and strategies are consequently needed to develop information based on at cellular and molecular level.

\section{REFERENCES}

[1] Sheela JAH. Qualitative analysis of secondary metabolites of the plant Clematis gouriana. Int $\mathrm{J}$ Innov Res Sci Eng Technol 2013; 2: 2356-2358.

[2] Jacobo-Vela'zquez DA, Gonza'lez-Aguero M, CisnerosZevallos L. Cross-talk between signalling pathways: The link between plant secondary metabolite production and wounding stress response. Sci Rep 2015; 5: 1-10.

[3] Kennedy DO, Wightman EL. Herbal Extracts and Phytochemicals: Plant Secondary Metabolites and the Enhancement of Human Brain Function. Adv Nutr 2011; 2: 32-50. http://dx.doi.org/10.3945/an.110.000117

[4] Akula R, Ravishankar GA. Influence of abiotic stress signals on secondary metabolites in plants. Plant Sig Behav 2011; 6: 1720-1731.

http://dx.doi.org/10.4161/psb.6.11.17613

[5] Canter $\mathrm{PH}$, Thomas $\mathrm{H}$, Ernst E. Bringing medicinal plants into cultivation: opportunities and challenges for biotechnology. Trends Biotechnol 2005; 23: 180-185. http://dx.doi.org/10.1016/j.tibtech.2005.02.002
[6]

Rao RS, Ravishankar GA. Plant cell cultures: chemical factories of secondary metabolites. Biotechnol Adv 2002; 20: 101-153. http://dx.doi.org/10.1016/S0734-9750(02)00007-1

[7] Fridman E, Pichersky E. Metabolomics, genomics, proteomics, and the identification of enzymes and their substrates and products. Curr Opin Plant Biol 2005; 8(3): 242-248.

http://dx.doi.org/10.1016/.j.pbi.2005.03.004

[8] Mandolino G, Carboni A. Potential of marker assisted selection in hemp genetic improvement. Euphytica 2004; 140: $107-120$.

http://dx.doi.org/10.1007/s10681-004-4759-6

[9] Turlings TCJ, Loughrin JH, McCall PJ, Röse USR, Lewis WJ, Tumlinson JH. How caterpillar-damaged plants protect themselves by attracting parasitic wasps. PNAS 1995; 92: 4169-4174. http://dx.doi.org/10.1073/pnas.92.10.4169

[10] Berli FJ, Moreno D, Piccolo P et al. Abscisic acid is involved in the response of grape (Vitis vinifera L.) cv. Malbec leaf Tissues to ultraviolet- $B$ radiation by enhancing ultraviolet absorbing compounds, antioxidant enzymes and membrane sterols. Plant Cell Environ 2010; 33(1): 1-10.

[11] Gupta VN, Datta SK. Influence of gibberellic acid on growth and flowering in chrysanthemum (Chrysanthemum morifolium Ramat) cv. Jayanti. Indian J Plant Physiol 2001; 6: 420-422.

[12] Ouzouidou G, Llias I. Hormone induced protection of sunflower photosynthetic apparatus against copper toxicity. Plant Biol 2005; 49: 223-228. http://dx.doi.org/10.1007/s10535-005-3228-y

[13] Mordue AJ, Blackwell A. Azadirachtin: an update. J Insect Physiol 1993; 39: 903-924.

http://dx.doi.org/10.1016/0022-1910(93)90001-8

[14] Eisner T, Meinwald J. Chemical ecology: The chemistry of biotic interaction. Eds, National Academy Press, Washington, DC 1995; 214 pp.

[15] Wuyts N, Lognay G, Swennen R, Waele DD. Nematode infection and reproduction in transgenic and mutant Arabidopsis and Tobacco with an altered phenylpropanoid metabolism. J Exp Bot 2006; 57(11): 2825-2835.

http://dx.doi.org/10.1093/jxb/erl044

[16] Savirnata NM, Jukunen-Titto R, Oksanen E, Karjalainen RO. Leaf phenolic compounds in red clover (Trifolium pratense L.) induced by exposure to moderately elevated ozone. Env Poll 2010; 158(2): 440-446. http://dx.doi.org/10.1016/j.envpol.2009.08.029

[17] Brooker N, Windorski J, Blumi E. Halogenated coumarin derivatives as novel seed protectants. Commun Agric Appl Biol Sci 2008; 73(2): 81-89.

[18] Serghini K, Perez De Lugue A, Castejon MM, Garcia TL, Jorrin JV. Sunflower (Helianthusannuus L.) response to broomraoe (Orobanche cernua Loefl.) parasitism: induced synthesis and excretion of 7-hydroxylated simple coumarins. $J$ Exp Bot 2001; 52: 227-234.

[19] Ali ST, Mahmooduzzafar-Abdin MZ, Iqbal M. Ontogenetic changes in foliar features and psoralen content of Psoralea corylifolia Linn. Exposed to $\mathrm{SO}_{2}$ stress. J Environ Biol 2008; 29(5): 661-668.

[20] Lewis N, Yamamoto E. Lignin: occurrence, biogenesis and biodegradation. Annu Rev Plant Physiol Plant Mol Biol 1990; 41: 455-496.

http://dx.doi.org/10.1146/annurev.pp.41.060190.002323

[21] Gould JM. Probing the structure and dynamics of lignin in situ. What's new in Plant Physiol 1983; 14: 5-8.

[22] Kondo T, Yoshida K, Nakagawa A, Kawai T, Tamura H, Goto T. Structural basis of blue-color development in flower petals from Commelina communis. Nature 1992; 358: 515-518. http://dx.doi.org/10.1038/358515a0 
[23] Lake JA, Field KJ, Davey MP, Beerling DJ, Lomax BH. Metabolomic and physiological responses reveal multi-phasic acclimation of Arabidopsis thaliana to chronic UV radiation. Plant Cell Environ 2009; 32(10): 1377-1389. http://dx.doi.org/10.1111/j.1365-3040.2009.02005.x

[24] Sreevidya VS, Srinivasa RC, Rao C, Sullia SB, Ladha JK, Reddy PM. Metabolic engineering of rice with soybean isoflavone synthase for promoting nodulation gene expression in rhizobia. J Exp Bot 2006; 57(9): 1957-1969. http://dx.doi.org/10.1093/jxb/erj143

[25] Posmyk MM, Kontek R, Janas KM. Antioxidant enzymes activity and phenolic compounds content in red cabbage seedlings exposed to copper stress. Ecotoxicol Environ Safety 2009; 72(2): 596-602. http://dx.doi.org/10.1016/i.ecoenv.2008.04.024

[26] Novak K, Lisa L, Skrdleta V. Rhizobial nod gene-inducing activity in pea nodulation mutants: Dissociation of nodulation and flavonoid response. Physiol Plant 2004; 120(4): 546-555. http://dx.doi.org/10.1111/j.0031-9317.2004.0278.x

[27] Oates JF, Waterman PG, Choo GM. Food selection by the south Indian leaf monkey, Presbytis johnii in relation to leaf chemistry. Oecologia 1980; 45: 45-56. http://dx.doi.org/10.1007/BF00346706

[28] Mayer AM. Polyphenols oxidase in plants recent progress. Phytochem 1987; 26: 11-20. http://dx.doi.org/10.1016/S0031-9422(00)81472-7

[29] Kang SY, Kim YC. Decursinol and decursin protect primary cultured rat cortical cells from glutamate-induced neurotoxicity. J Pharm Pharmacol 2007; 59(6): 863-870. http://dx.doi.org/10.1211/jpp.59.6.0013

[30] Gutiérrez-Alcalá G, Gotor C, Meyer AJ, Fricker M, Vega JM, Romero LC. Glutathione biosynthesis in Arabidopsis trichome cells. PNAS 2000; 97: 11108-11113.

http://dx.doi.org/10.1073/pnas.190334497

[31] Choi YE, Harada E, Wada $\mathrm{M}$ et al. Detoxification of cadmium in tobacco plants: Formation and active excretion of crystal containing cadmium and calcium through trichomes. Planta 2001; 213: 45-50.

http://dx.doi.org/10.1007/s004250000487

[32] Nosito FF, Pirovano L, Cocucci M, Sacchi GA. Cadmiuminduced sulphate uptake in maize roots. Plant Physiol 2002; 129: $1872-1879$

http://dx.doi.org/10.1104/pp.002659

[33] Conklin PL, Barth C. Ascorbic acid, a familiar small molecule intertwined in the response of plants to ozone, pathogens, and the onset of senescence. Plant Cell Environ 2004; 27: 959-970.

http://dx.doi.org/10.1111/j.1365-3040.2004.01203.x

[34] Foyer $\mathrm{CH}$, Rennenberg $\mathrm{H}$. Regulation of glutathione synthesis and its role in abiotic and biotic stress defence. In: Brunold C, Rennenberg H, De Kok LJ, Stulen L, Davidian JC (Eds.) Sulphur Nutrition and Sulphur Assimilation in Higher Plants. Bern: Paul Haupt 2000; pp. 127-153.

[35] De Vos M, Jander G. Myzus persicae (gren peach aphid) salivery components induce defence responses in Arabidopsis thaliana. Plant Cell Environ 2009; 32(11): 15481560.

http://dx.doi.org/10.1111/j.1365-3040.2009.02019.x

[36] Leustek T. Sulphate metabolism. Somerville CR, Meyerowitz EM, eds, The Arabidopsis Book. American Society of Plant Biologists, Rockville, MD, 2002.

[37] Grubb C, Abel S. Glucosinolate metabolism and its control. Trends Plant Sci 2006; 11: 89-100. http://dx.doi.org/10.1016/j.tplants.2005.12.006

[38] Geu-Flores F, Olsen C, Halkier BA. Towards engineering glucosinolates into non- cruciferous plants. Planta 2009; 229(2): 261-270.

http://dx.doi.org/10.1007/s00425-008-0825-y
[39] Lipka U, Fuchs R, Kuhns C, Petutschnig E, Lipka V. Live and let die-Arabidopsis non-host resistance to powdery mildews. Eur J Cell Biol 2010; 89(2): 194-199. http://dx.doi.org/10.1016/i.ejcb.2009.11.011

[40] Monde K, Osawa SM, Harada N et al. Synthesis and absolute stereo chemistry of a cruciferous phytoalexin, Spirobrassinin. Chem Lett 2000; 598: 886-887. http://dx.doi.org/10.1246/cl.2000.886

[41] Van Loon LC, Pierpoint WS, Boller T, Conejero V. Recommendations for naming plant pathogenesis-related proteins. Plant Mol Biol Rep 1994; 12: 245-264. http://dx.doi.org/10.1007/BF02668748

[42] Thomma BPHJ, Cammue BPA, Thevissen K. Plant defensins. Planta 2002; 216(2): 193-202. http://dx.doi.org/10.1007/s00425-002-0902-6

[43] Parashina EV, Serdobinskii LA, Kalle EG et al. Genetic engineering of oilseed rape and tomato plants expressing a radish defensin gene. Russ J Plant Physiol 2000; 47: 417423.

[44] Peumans WJ, Van DEJM. Lectins as plant defence proteins. Plant Physiol 1995; 109(2): 347-352. http://dx.doi.org/10.1104/pp.109.2.347

[45] Hegnauer R. Biochemistry, distribution and taxonomic relevance of higher plant alkaloids. Phytochem 1988; 27: 2423-2427.

http://dx.doi.org/10.1016/0031-9422(88)87006-7

[46] Hartmann T. Alkaloids. Herbivores: Their interactions with secondary plant metabolites Vol I The chemical participants $2^{\text {nd }}$ ed., Rosenthal GA and Berenbaum MR (Eds.) Academic Press, San Diego 1991; pp. 33-85.

[47] Ballhorn DJ, Kautz S, Heil M, Hegeman AD. Cyanogenesis of wild lima bean (Phaseolus lunatus L.) is an efficient direct defence in nature. Plant Signal Behav 2009; 4(8): 735-745. http://dx.doi.org/10.1371/journal.pone.0005450

[48] Shalaka DK, Sandhya P. Micropropagation and organogenesis in Adhatoda vasica for the estimation of vasine. Pharmacogn Mag 2009; 5: 539-363.

[49] Maurya S, Singh D. In vitro callus culture of Adhatoda vasica: a medicinal plant. Ann Biol Res 2010; 1(4): 57-60.

[50] Singh B, Sharma RA. Pyrroloquinazoline alkaloids from tissue cultures of Adhatoda vasica and their antioxidative activity. Am J Phytomed Clin Therapeut 2014; 2: 403-412.

[51] Lee SY, Cho SJ, Park MH, Kim YK, Choi JI, Park SU. Growthand rutin production in hairy root culture of buck weed (Fagopyruum esculentum) Prep. Biochem. Biotechnol 2007; 37: 239-246. http://dx.doi.org/10.1080/10826060701386729

[52] Roy D, Mukhopadhyay S. Enhanced rosmarinic acid production in cultured plants of two species of Mentha. Indian J Exp Biol 2012; 50(11): 817-825.

[53] Bauer N, Leljak-Levanic D, Jelaska S. Rosmarinic acid synthesis in transformed callus culture of Coleusblumei Benth. Z Naturforsch 2004; 59: 554-560.

[54] Hakkim LF, Kalyani S, Essa M, Girija S, Song H. Production of rosmarinic acid in Ocimum sanctum (I.) cell suspension cultures by the influence of growth regulators. Int $\mathrm{J}$ Biol Med Res 2011; 2(4): $1158-1161$.

[55] Yang L, Cao YL, Jiang JG, Lin QS, Chen J, Zhu L. Response surface optimization of ultrasound-assisted flavonoids extraction from the flower of Citrus aurantium L. var. amara. Engl J Sep Sci 2010; 33: 1349-1355.

[56] Krolicka A, Kartanowicz R, Wosinskia S, Zpitter A, Kaminski M, Lojkowska E. Induction of secondary metabolite production in transformed callus of Ammi majus L. grown after electromagnetic treatment of the culture medium Enzyme Microb Technol 2006; 39: 1386-1389. http://dx.doi.org/10.1016/j.enzmictec.2006.03.042 
[57] Staniszewska I, Krolicka A, Mali E, Ojkowska E, Szafranek J. Elicitation of secondary metabolites in in vitro cultures of Ammi majus L. Enzyme Microb Technol 2003; 33: 565-568. http://dx.doi.org/10.1016/S0141-0229(03)00180-7

[58] Yaoya S, Kanho H, Mikami Y, Itani T, Umehara K, Kuroyanagi M. Umbelliferone released from hairy root cultures of Pharbitis nil (L.) treated with copper sulphate and its subsequent glucosylation. Biosci Biotechnol Biochem, 2004; 68: 1837-1841.

http://dx.doi.org/10.1271/bbb.68.1837

[59] Ikuta A, Kamiya K, Satakek T, Saiki Y. Triterpenoids from callus cultures of Paeonia species. Phytochem 1995; 38: 1203-1207.

http://dx.doi.org/10.1016/0031-9422(94)00445-Y

[60] Swain SS, Rout KK, Chand PK. Production of anti-cancer compound taraxerol in Agrobacterium-transformed root cultures of butterfly pea (Clitoria ternatea L.). Appl Biochem Biotechnol, 2012; 168(3): 487-503.

http://dx.doi.org/10.1007/s12010-012-9791-8

[61] Xu H, Kim YK, Suh SY, Udin MR, Lee SY, Park SU. Decursin production from hairy root culture of Angelica gigas. J Korean Soc Appl Biol Chem 2008; 51: 349-351. http://dx.doi.org/10.3839/jksabc.2008.062

[62] Kim JS, Lee SY, Park SU. Resveratol production in hairy root culture of peanut, Arachis hypogaea L. transformed with different Agrobacterium rhizogenes strains. Afr J Biotechnol 2008; 7: 3788-3790.

[63] Condori J, Sivakumar G, Hubstenberger J, Dolan MC, Sobolev VS, Medina-Bolivar F. Induced biosynthesis of resveratrol and the prenylated stilbenoids arachidin-1 and arachidin-3 in hairy root cultures of peanut: Effects of culture medium and growth stage. Plant Physiol Biochem 2010; 48: 310-318. http://dx.doi.org/10.1016/j.plaphy.2010.01.008

[64] Keskin N, Kunter B. Production of trans-resveratrol in callus tissue of öküzgözü (Vitis vinifera L.) in response to ultravioletc irradiation. J Anim Plant Sci 2010; 20(3): 197-200.

[65] Yu SH, Zha JP, Zhan WH, Zhang DQ. Contents comparison of resveratrol and polydatin in the wild Polygonum cuspidatum plant and its tissue cultures. China J Chinese Mat Med 2006; 31(8): 637-641.

[66] Baldi A, Dixit VK. Enhanced artemisinin production by cell cultures of Artemisia annua. Curr Trends Biotechnol Pharm 2008; 2: 341-348.

[67] Nair MSR, Acton N, Klayma DL. Production of Artemisinin in tissue cultures of Artemisia annua. J Nat Prod 1986; 49: 504507. http://dx.doi.org/10.1021/np50045a021

[68] Olivira AJB, Koike L, Reis FAM, Shepherd SLK. Callus culture of Aspidosperma ramiflorum Muell.-Arg.: growth and alkaloid production. Acta Scientia 2001; 23: 609-612.

[69] Sujanya S, Poornasri DB, Sai I. In vitro production of azadirachtin from cell suspension cultures of Azadirachta indica. J Biosci 2008; 33: 113-120. http://dx.doi.org/10.1007/s12038-008-0027-6

[70] Srivastava P, Chaturvedi R. Increased production of azadirachtin from an improved method of androgenic cultures of a medicinal tree Azadirachta indica A. Juss Plant Signal Behav 2011; 6(7): 974-981. http://dx.doi.org/10.4161/psb.6.7.15503

[71] Singh $M$, Chaturvedi R. Sustainable production of azadirachtin from differentiated in vitro cell lines of neem (Azadirachta indica). AoB Plants 2013; 1-14. http://dx.doi.org/10.1093/aobpla/plt034

[72] Srivastava S, Srivastava AK. Azadirachtin production by hairy root cultivation of Azadirachta indica in a modified stirred tank reactor. Bioprocess Biosyst Eng 2012; 35(9): 1549-1553. http://dx.doi.org/10.1007/s00449-012-0745-x
[73] Satdive RK, Fulzele DP, Eapen S. Enhanced production of azadirachtin by hairy root cultures of Azadirachta indica A. Juss by elicitation and media optimization. J Biotechnol 2007; 128: 281-289.

http://dx.doi.org/10.1016/j.jbiotec.2006.10.009

[74] Wagiah ME, Alam G, Wiryowidagdo S, Attia K. Improved production of the indole alkaloid cathin-6-one from cell suspension cultures of Brucea javanica (L.) Merr. Indian J Sci Technol 2008; 1: 1-6.

[75] Kusakari K, Yokoyama M, Inomata S. Enhanced production of saikosaponins by root culture of Bupleurum falcatum $\mathrm{L}$. using two step control of sugar concentration. Plant Cell Rep 2000; 19: 1115-1120. http://dx.doi.org/10.1007/s002990000240

[76] Hao J, Guan Q. Synthesis of saikosaponin in adventitious roots of Bupleurum chinense by semi-continuous culture. Plant Cell Tiss Organ Cult 2012; 108: 159-165. http://dx.doi.org/10.1007/s11240-011-0012-x

[77] Nikolaeva TN, Zagoskina NV, Zaprometov MN. Production of phenolic compounds in callus cultures of tea plant under the effect of 2, 4-D and NAA. Russ J Plant Physiol 2009; 56: 4549. http://dx.doi.org/10.1134/S1021443709010075

[78] Umamaheswari A, Lalitha V. In vitro effect of various growth hormones in Capsicum annuum L. On the callus induction and production of capsaicin. J Plant Sci 2007; 2: 545-551. http://dx.doi.org/10.3923/jps.2007.545.551

[79] Kehie M, Kumaria S, Tandon P. In vitro plantlet regeneration from nodal segments and shoot tips of Capsicum chinense Jacq. cv. Naga King Chili. 3Biotech 2012; 2: 31-35.

[80] Kehie M, Kumaria S, Tandon P. Manipulation of culture strategies to enhance capsaicin biosynthesis in suspension and immobilized cell cultures of Capsicum chinense Jacq. cv. Naga King Chili. Bioprocess Biosyst Eng 2014; 37(6): 10551063.

http://dx.doi.org/10.1007/s00449-013-1076-2

[81] Nazif NM, Rady MR, Seif MM. Stimulation of anthraquinone production in suspension cultures of Cassia acutifolia by salt stress. Fitoterapia 2000; 71: 34-40. http://dx.doi.org/10.1016/S0367-326X(99)00101-X

[82] Supe U. Analysis of anthraquinone by callus tissue of Aloe barbadensis. Rec Res Sci Tech 2013; 5(2): 54-56.

[83] Deshmukh SR, Wadegaonkar VP, Bhagat RP, Wadegaonkar PA. Tissue specific expression of Anthraquinones, flavonoids and phenolics in leaf, fruit and root suspension cultures of Indian Mulberry (Morinda citrifolia L.). Plant Omics J 2011; 4(1): 6-13.

[84] Huang B, Lin H, Yan C, Qiu H, Qiu L, Yu R. Optimal inductive and cultural conditions of Polygonum multiflorum transgenic hairy roots mediated with Agrobacterium rhizogenes R1601 and an analysis of their anthraquinone constituents. Pharmacogn Mag 2014; 10(37): 77-82. http://dx.doi.org/10.4103/0973-1296.126671

[85] Baque MA, Shiragi MHK, Lee EJ, Paek KY. Elicitor effect of chitosan and pectin on the biosynthesis of anthraquinones, phenolics and flavonoids in adventitious root suspension cultures of Morinda citrifolia (L.). Aust J Crop Sci 2012; 6(9): 1349-1355.

[86] Komaraiah P, Kishor PBK, Carlsson M, Magnusson KE, Mandenius CF. Enhancement of anthraquinone accumulation in Morinda citrifolia suspension cultures. Plant Sci 2005; 168: 1337-1344. http://dx.doi.org/10.1016/j.plantsci.2005.01.017

[87] Ataei-Azimi A, Delnavaz Hashemloian B, Ebrahimzade $\mathrm{H}$, Majd A. High in vitro production of anticanceric indole alkaloid from periwinkle (Catharanthus roseus) tissue culture. Afr J Biotechnol 2008; 7: 2834-2839. 
[88] Lee-Parsons CWT, Rogce AJ. Precursor limitations in methyl jasmonate induced Catharanthus roseus cell cultures. Plant Cell Rep 2006; 25: 607-612. http://dx.doi.org/10.1007/s00299-005-0109-y

[89] Verma AK, Singh RR, Singh S. Improved alkaloid content in callus culture of Catharanthus roseus. Bot Serb 2012; 36 (2): (2012) $123-130$

[90] Kalidass C, Ramasamy V, Danie MA. Effect of auxin and cytokinin on vincristine production by callus cultures of Catharanthus roseus L. Trop Subtrop Agroecosys 2010; 12: $283-288$.

[91] Ramani S, Jayabaskaran C. Enhanced catharathine and vindoline production in suspension cultures of Catharanthus roseus by ultraviolet-B light. J Mol Signal 2008; 3: 9-14. http://dx.doi.org/10.1186/1750-2187-3-9

[92] Roat C, Ramawat KG. Elicitor induced accumulation of stilbenes in cell suspension cultures of Cayratia trifoliata (L.) Domin. Plant Biotechnol Rep 2009; 3: 135-138. http://dx.doi.org/10.1007/s11816-009-0082-y

[93] Kim OT, Bang KH, Shin YS, Lee MJ. Enhanced production of asiaticoside from hairy root cultures of Centella asiatica [L.] Urban elicited by methyl jasmonate. Plant Cell Rep 2007; 26(11): 1941-1949.

http://dx.doi.org/10.1007/s00299-007-0400-1

[94] Kiong AL, Mahmood M, Fodzillan NM, Daud SK. Effects of precursor supplementation on the production of triterpenes by Centella asiatica callus culture. Pak J Biol Sci 2005; 8: 1160-1169.

http://dx.doi.org/10.3923/pjbs.2005.1160.1169

[95] Hiraoka N, Bhatt ID, Sakurai Y, Chang J. Alkaloid production by somatic embryo cultures of Corydalis ambigua. Plant Biotechnol 2004; 21: 361-366. http://dx.doi.org/10.5511/plantbiotechnology.21.361

[96] Narasimhan S, Nair GM. Proceedings of the International Symposium on Plant Biodiversity: Conservation and Evaluation, Bose Institute, Kolkata pp. 2002; 78-79.

[97] Hohtola A, Jalonen J, Tolnen A, et al. Natural product formation by plants, enhancement, analysis, processing and testing. In: Sustainable use renewable natural resources from principles to practices (Eds.) Jalkanen $A$ and Nygren $P$. University of Helsinki Publication. 2005; pp. 34-69.

[98] Shohael AM, Murthy HN, Hahn EJ, Paek KY. Methyl jasmonate induced overproduction of eleuthrosides in somatic embryos of Eleutherococcus senticosus cultured in bioreactors. Electron J Biotechnol 2007; 10: 633-637. http://dx.doi.org/10.2225/vol10-issue4-fulltext-13

[99] Schmeda-Hirschmann G, Jordan M, Gertn A, Wilken D, Hormazabal E, Tapia AA. Secondary metabolite content in Fabiana imbricate plants and in vitro cultures. Z Naturforsch 2004; 59: 48-54.

[100] Lee SY, Xu H, Kim YK, Park SU. Rosmarinic acid production in hairy root cultures of Agastache rugosa Kuntze. World $\mathrm{J}$ Microbiol Biotechnol 2007; 20: 969-972.

[101] Gao SL, Zhu DN, Cai ZH, Jiang Y, Xu DR. Organ culture of a precious Chinese medicinal plan - Fritillaria unibracteata. Plant Cell Tiss Org Cult 1999; 59: 197-201. http://dx.doi.org/10.1023/A:1006440801337

[102] Tiwari RK, Trivedi M, Guang ZC, Guo GQ, Zheng GC. Genetic transformation of Gentiana macrophylla with Agrobacteriumrhizogenes: growth and production of secoiriDOld glucoside gentiopicroside in transformed hairy root cultures. Plant Cell Rep 2007; 26: 199-210. http://dx.doi.org/10.1007/s00299-006-0236-0

[103] Vinterhalter B, Jankovic T, Sovikin L, Nikolic R, Vinterhalter D. Propagation and xanthone content of Gentianella austriaca shoot cultures. Plant Cell Tiss Org Cult 2008; 94: 329-335.

http://dx.doi.org/10.1007/s11240-008-9374-0
[104] Mehrotra S, Kukreja AK, Khanuja SPS, Mishra BN. Genetic transformation studies and scale up of hairy root culture of Glycyrrhiza glabra in bioreactor. Electron J Biotechnol 2008; 11(2): 1-7.

http://dx.doi.org/10.2225/vol11-issue2-fulltext-6

[105] Gopi C, Vatsala TM. In vitro studies on effects of plant growth regulators on callus and suspension culture biomass yield from Gymnema sylvestre R.Br. Afr J Biotechnol 2006; 5: 1215-1219.

[106] Misra N, Misra P, Datta SK, Mehrotra S. In vitro biosynthesis of antioxidants from Hemidesmus indicus R.Br. cultures. In Vitro Cell Dev Biol Plant 2005; 41: 285-290. http://dx.doi.org/10.1079/IVP2004627

[107] Kornfeld A, Kaufman PB, Lu CR et al. The production of hypericins in two selected Hypericum perforatum shoot cultures is related to differences in black gland structure. Plant Physiol Biochem 2007; 45: 24-32. http://dx.doi.org/10.1016/j.plaphy.2006.12.009

[108] Phatak SV, Heble MR. Organogenesis and terpenoid synthesis in Mentha arvensis. Fitoterapia 2002; 73(1): 32-39. http://dx.doi.org/10.1016/S0367-326X(01)00347-1

[109] Agarwal M, Kamal R. Studies on flavonoid production using in vitro cultures in Momordica charantia L. Indian J Biotechnol 2007; 6: 277-279.

[110] Khosroushahi AY, Valizadeh M, Ghasempour A, Khosrowshahli M, Naghdibadi H, Dadpour MR. Improved Taxol production by combination of inducing factors in suspension cell culture of Taxus baccata. Cell Biol Int 2006; 30(3): 262-269

http://dx.doi.org/10.1016/i.cellbi.2005.11.004

[111] Wu J, Wang C, Mei X. Stimulation of taxol production and excretion in Taxus spp. cell cultures by rare earth chemical lanthanum. J Biotechnol 2001; 85: 67-73.

http://dx.doi.org/10.1016/S0168-1656(00)00383-7

[112] Nguyen T, Eshraghi J, Gonyea G, Ream R, Smith R. Studies on factors influencing stability and recovery of paclitaxel from suspension media and cultures of Taxus cuspidata cV Densiformis by high-performance liquid chromatography. $J$ Chromatogr -A 2001; 911: 55-61. http://dx.doi.org/10.1016/S0021-9673(00)01272-3

[113] Yu KW, Gao WY, Hahn EJ, Paek KY. Jasmonic acid improves Ginsenoside accumulation in adventitious roo culture of Panax ginseng. J Biochem Eng 2002; 11: 211-215. http://dx.doi.org/10.1016/S1369-703X(02)00029-3

[114] Park SU, Facchini PJ. Agrobacterium-mediated genetic transformation of California poppy Eschscholzia californica via somatic embryogenesis. Plant Cell Rep 2000; 19: 421426. http://dx.doi.org/10.1007/s002990050750

[115] Diarra ST, He J, Wang J, Li J. Ethylene treatment improves diosgenin accumulation in in vitro cultures of Dioscorea zingiberensis via upregulation of CAS and HMGR gene expression. Electron J Biotechnol 2013; 16(5): 1-10.

[116] Li B, Dobruchowska JM, Gerrit JG, Dijkhuizen L, Kamerling JP. Structural investigation of water-soluble polysaccharides extracted from the fruit bodies of Coprinus comatus. Carbohydr Polym, 2013; 91: 314-321. http://dx.doi.org/10.1016/j.carbpol.2012.08.045

[117] Jennewein S, Park H, Dejong JM, Long RM, Bollon AP, Croteau RB. Coexpression in yeast of Taxus cytochrome P450 reductase with cytochrome $\mathrm{P} 450$ oxygenases involved in taxol biosynthesis. Biotechnol Bioeng 2005; 89: 588-598. http://dx.doi.org/10.1002/bit.20390

[118] Liao Z, Chen M, Sun X, Tang K. Micropropagation of endangered plant species. Methods Mol Biol 2006; 318: 179185.

[119] Christen AA, Bland J, Gibson GM. Cell culture as a means to produce taxol. Proc Am Assoc Cancer Res 1989; 30: 566. 
[120] Kim JH, Yun JH, Hwang YS, Byun SY, Kim DI. Production of taxol and related taxanes in Taxus brevifolia cell cultures: Effect of sugar. Biotechnol Lett 1995; 17: 101-106. http://dx.doi.org/10.1007/BF00134204

[121] Ketchum REB, Rithner CD, Qiu D, Kim YS, Williams RM, Croteau RB. Taxus metabolites: methyl jasmonates preferentially induces production of taxoids oxygenated at C13 in Taxus media cell cultures. Phytochem 2003; 62: 901909. http://dx.doi.org/10.1016/S0031-9422(02)00711-2

[122] Parc G, Canaguier A, Landr P, Hocquemiller R, Chriqui D, Meyer M. Production of taxoids with biological activity by plants and callus cultures from selected Taxus genotypes. Phytochem 2002; 59: 725-730. http://dx.doi.org/10.1016/S0031-9422(02)00043-2

[123] Long RM, Croteau R. Preliminary assessment of the C13side chain 2'-hydroxylase involved in taxol biosynthesis. Biochem Biophys Res Commun 2005; 338: 410-417. http://dx.doi.org/10.1016/j.bbrc.2005.08.119

[124] Zhao J, Davis LC, Verpoorte R. Elicitor signal transduction leading to production of plant secondary metabolites. Biotechnol Adv 2005; 23: 283-333. http://dx.doi.org/10.1016/j.biotechadv.2005.01.003

[125] Pichersky E, Lewinsohn E. Convergent evolution in plant specialized metabolism. Annu Rev Plant Biol 2011; 62: 549566.

http://dx.doi.org/10.1146/annurev-arplant-042110-103814

[126] Tisserat B, Berhow M. Production of pharmaceuticals from Papaver cultivars in vitro. Eng Life Sci 2009; 9: 190-196. http://dx.doi.org/10.1002/elsc.200800100

[127] Palazon J, Moyano E, Bonfill M, Cusido RM, Pinol MT. Floriculture, Ornamental and Plant Biotechnology: Advances and Topical Issues. Teixeira da Silva, J. A., Eds.; Global Science Books, Ltd: London, UK 2006; pp. 209-221.

[128] Sharma D, Bhatia V, Patil S, Sharma PC. Antimicrobial activity of selected cryptogams from solan region. Int $\mathrm{J}$ Biol Pharm Res 2013; 4(6): 448-454.

[129] Srivastava S, Srivastava AK. Hairy root culture for massproduction of high-value secondary metabolites. Crit Rev Biotechnol 2007; 27: 29-43. http://dx.doi.org/10.1080/07388550601173918

[130] Hu WW, Yao HU, Zhong JJ. Improvement of Panax notoginseng cell cultures for production of ginseng saponin and polysaccharide by high-density cultivation of pneumatically agitated bioreactors. Biotechnol Prog 2001; 17: 838-846. http://dx.doi.org/10.1021/bp010085n

[131] Debnath M, Malik CP, Bisen PS. Micropropagation: A tool for the production of high quality plant-based medicines. Curr Pharm Biotechnol 2006; 7: 33-49.

http://dx.doi.org/10.2174/138920106775789638

[132] Sarin R. Useful metabolites from plant tissue cultures. Biotechnol 2005; 4: 79-93.

http://dx.doi.org/10.3923/biotech.2005.79.93

[133] Zhang Q, Rich JO, Cotterill IC, Pantaleone DP, Michels PC. 14-Hydroxylation of opiates: Catalytic direct autoxidation of codeinone to 14-hydroxycodeinone. J Am Chem Soc 2005; 127: 7286-7287.

http://dx.doi.org/10.1021/ja051682z

[134] Wang W, Zhong JJ. Manipulation of ginsenoside heterogeneity in cell cultures of Panax notoginseng by addition of jasmonates. J Biosci Bioeng 2002; 93: 48-53. http://dx.doi.org/10.1016/S1389-1723(02)80053-6

[135] Huang SM, Bisogno T, Trevisani $M$ et al. An endogenous capsaicin-like substance with high potency at recombinant and native vanilloid VR1 receptors. PNAS 2002; 99(12): 8400-8405.

http://dx.doi.org/10.1073/pnas.122196999
[136] Vanisree M, Lee C, Nalawade SM, Lin CY, Tasy H. Studies on the production of some important secondary metabolite from medicinal plants by Plant tissue culture. Bot Bull Acad Sin 2004; 45: 1-22.

[137] Dubey NK, Kumar R, Tripathi P. Global promotion of herbal medicine: India's opportunity. Curr Sci 2004; 80: 37-41.

[138] Eibl R, Eibl D. Plant Tissue Culture Engineering (Focus on Biotechnology), vol 6. Gupta, SD, Ibaraki Y, Eds.; Springer: Berlin-Heidelberg-New York, pp. 2006; 203-227.

[139] Zhu W, Zhu JY, Gleisner R, Pan XJ. On energy consumption for size-reduction and yield from subsequent enzymatic sacchrification of pretreated lodgepole pine. Bioresour Technol 2010; 101(8): 2782-2792. http://dx.doi.org/10.1016/j.biortech.2009.10.076

[140] Ravishankar GA, Suresh B, Giridhar P, Rao SR, Johnson TS. Biotechnological studies on capsicum for metabolite production and plant improvement. In: DE, Amit Krishna ed. Capsicum: The genus Capsicum. Harwood Academic Publishers, UK, 2003; pp. 96-128.

[141] Sharma A, Kumar V, Giridhar P, Ravishankar GA. Induction of in vitro flowering in Capsicum frutescens under the influence of silver nitrate and cobalt chloride and pollen transformation. Plant Biotechnol 2008; 11: 1-8. http://dx.doi.org/10.2225/vol11-issue2-fulltext-8

[142] Ravishankar GA, Ramachandra Rao S. Biotechnological production of phyto-pharmaceuticals. J Biochem Mol Biol Biophys 2000; 4: 73-102.

[143] Sanatombi K, Sharma GJ. Micropropagation of Capsicum frutescens L. using axillary shoot explants. Sci Hort 2007; 113: 96-99.

http://dx.doi.org/10.1016/j.scienta.2007.01.020

[144] Padmanabha BV, Chandrashekar M, Ramesha BT et al. Patterns of accumulation of camptothecin, an anti-cancer alkaloid in Nothapodytes nimmoniana Graham, in the Western Ghats, India: Implications for identifying highyielding sources of the alkaloid. Curr Sci 2006; 90: 95-100.

[145] Lu D, Dong J, Jin $\mathrm{H}$ et al. Nitrate reductase-mediated nitric oxide generation is essential for fungal elicitor-induced camptothecin accumulation of Camptotheca acuminata suspension cell cultures. Appl Microbiol Biotechnol 2011; 90(3): 1073-1081.

http://dx.doi.org/10.1007/s00253-011-3146-1

[146] Oksman-Caldentey KM, Inze D. Plant cell factories in the post genomic era: new ways to produce designer secondary metabolites. Trends Plant Sci 2004; 9: 433-440. http://dx.doi.org/10.1016/j.tplants.2004.07.006

[147] Aslam J, Mujib A, Nasim SA, Sharma MP. Screening of vincristine yield in ex vitro and in vitro somatic embryos derived plantlets of Catharanthus roseus L. (G) Don. Sci Hort 2009; 119: 325-329.

http://dx.doi.org/10.1016/j.scienta.2008.08.018

[148] Verma A, Laakso I, Laakso TS, Huhtikangas A, Riekkola ML. A simplified procedure for indole alkaloid extraction from Catharanthus roseus combined with a semi-synthetic production process for vinblastine. Molecule 2007; 12: 13071315. http://dx.doi.org/10.3390/12071307

[149] Zhao J, Hu Q, Guo Q, Zhu WH. Effects of stress factors, bioregulators and synthetic precursor on indole alkaloid production in compact callus clusters cultures of Catharanthus roseus. Appl Microb Biotechnol 2001a; 55: 693- 698.

\section{http://dx.doi.org/10.1007/s002530000568}

[150] Zhao J, Zhu W, Hu Q. Enhanced catharanthine production in Catharanthus roseus cell cultures by combined elicitor treatment in shake flasks and bioreactors. Enzyme Microb Tech 2001b; 28: 673-681. http://dx.doi.org/10.1016/S0141-0229(01)00306-4 
[151] Guo ZG, Liu Y, Gong MZ, Chen W, Li WY. Regulation of vinblastine biosynthesis in cell suspension cultures of Catharanthus roseus. Plant Cell Tiss Org Cult 2013; 112(1): 43-54.

http://dx.doi.org/10.1007/s11240-012-0213-y

[152] Chattopadhyay S, Farkya S, Srivastava AK, Bisaria VS. Bioprocess Considerations for Production of Secondary Metabolites by Plant Cell Suspension Cultures. Biotechnol. Bioprocess Eng 2002; 7: 138-149. http://dx.doi.org/10.1007/BF02932911

[153] Koulman A, Beekman AC, Pras N, Quax WJ. The bioconversion process of deoxypodophyllotoxin with Linum flavum cell cultures. Planta Med 2003; 69: 739-744. http://dx.doi.org/10.1055/s-2003-42785

[154] Sevon N, Oksman-Caldentey KM. Agrobacterium rhizogenes-mediated transformation: root cultures as a source of alkaloids. Planta Med 2002; 68(10): 859-868. http://dx.doi.org/10.1055/s-2002-34924

[155] Choi PS, Cho DY, Soh WY. Plant regeneration from immature embryo cultures of Vigna unguiculata. Biol Plantarum 2003; 47: 305-308.

http://dx.doi.org/10.1023/B:BIOP.0000022272.39625.59

[156] Chen WP, Punja ZK. Transgenic herbicide and disease tolerant carrot (Daucus carota L.) plants obtained through Agrobacterium-mediated transformation. Plant Cell Rep 2002; 20: 929-935. http://dx.doi.org/10.1007/s00299-001-0419-7

[157] Chitty JA, Allen RS, Fist AJ, Larkin PJ. Genetic transformation in commercial Tasmanian cultivars of opium poppy, Papaver somniferum, and movement of transgenic pollen in the field. Funct Plant Biol 2003; 30: 1045-1058. http://dx.doi.org/10.1071/FP03126

[158] Borgio JF. RNA interference (RNAi) technology: a promising tool for medicinal plant research. J Med Plants Res 2009; 3(13): 1176-1183.

[159] Price DRG, Gatehouse JA. RNAi-mediated crop protection against insects. Trends Biotechnol 2008; 26(7): 393-400. http://dx.doi.org/10.1016/j.tibtech.2008.04.004

[160] Larkin PJ, Miller JAC, Allen RS et al. Increasing morphinan alkaloid production by over-expressing codeinone reductase in transgenic Papaver somniferum. Plant Biotechnol J 2007; 5: 26-37. http://dx.doi.org/10.1111/j.1467-7652.2006.00212.x

[161] Allen RS, Millgate AG, Chitty JA et al. RNAi-mediated replacement of morphine with the non-narcotic alkaloid reticuline in Opium poppy. Nat Biotechnol 2004; 22: 15591566.

http://dx.doi.org/10.1038/nbt1033

[162] Fujii N, Inui T, Iwasa K, Morishige T, Sato F. Knockdown of berberine bridge enzyme by RNAi accumulates (S)-reticuline and activates a silent pathway in cultured California poppy cells. Transgenic Res 2007; 16: 363-375.

http://dx.doi.org/10.1007/s11248-006-9040-4

[163] Runguphan W, Maresh JJ, O'Connor SE. Silencing of tryptamine biosynthesis for production of non-natural alkaloids in plant culture. PNAS 2009; 106(33): 1367313678.

http://dx.doi.org/10.1073/pnas.0903393106

[164] Mahmoud SS, Croteau R. Metabolic engineering of essential oil yield and composition in mint by altering expression of deoxyxylulose phosphate reductoisomerase and menthofuran synthase. PNAS 2001; 98: 8915-8920. http://dx.doi.org/10.1073/pnas.141237298

[165] Facchini PJ, Park SU. Developmental and inducible accumulation of gene transcripts involved in alkaloid biosynthesis in opium poppy. Phytochem 2003; 64: 177-186. http://dx.doi.org/10.1016/S0031-9422(03)00292-9

[166] Mahmoud SS, Williams M, Croteau R. Co-suppression of limonene-3-hydroxylase in peppermint promotes accumulation of limonene in the essential oil. Phytochem 2004; 65: 547-554.

http://dx.doi.org/10.1016/j.phytochem.2004.01.005

[167] Frick S, Chitty JA, Kramell R, Schmidt J, Allen RS, Larkin PJ. Transformation of opium poppy (Papaver somniferum L.) with antisense berberine bridge enzyme gene (anti-bbe) via somatic embryogenesis results in an altered ratio of alkaloids in latex but not in roots. Transgenic Res 2004; 13: 607-613. http://dx.doi.org/10.1007/s11248-004-2892-6

[168] Davuluri GR, van Tuinen A, Fraser PD et al. Fruit-specific RNAi-mediated suppression of DET1 enhances carotenoid and flavonoid content in tomatoes. Nat Biotechnol 2005; 23 : 890-895.

http://dx.doi.org/10.1038/nbt1108

[169] Underwood BA, Tieman DM, Shibuya $\mathrm{K}$ et al. Ethyleneregulated floral volatile synthesis in petunia corollas. Plant Physiol 2005; 138: 255-266. http://dx.doi.org/10.1104/pp.104.051144

[170] Verdonk JC, Haring MA, van Tunen AJ, Schuurink RC. ODORANT1 regulates fragrance biosynthesis in Petunia flowers. Plant Cell 2005; 17: 1612-1624. http://dx.doi.org/10.1105/tpc.104.028837

[171] Orlova I, Marshall-Colon A, Schnepp J et al. Reduction of benzenoid synthesis in petunia flowers reveals multiple pathways to benzoic acid and enhancement in auxin transport. Plant Cell 2006; 18: 3458-3475 http://dx.doi.org/10.1105/tpc.106.046227

[172] Van der Rest B, Danoun S, Boudet AM, Rochange SF. Down-regulation of cinnamoyl-CoA reductase in tomato (Solanum lycopersicum L.) induces dramatic changes in soluble phenolic pools. J Exp Bot 2006; 57: 1399-1411. http://dx.doi.org/10.1093/jxb/erj120

[173] Inui T, Tamura K, Fujii N, Morishige T, Sato F. Overexpression of Coptis japonica norcoclaurine 6- Omethyltransferase overcomes the rate-limiting step in benzylisoquinoline alkaloid biosynthesis in cultured Eschscholzia californica. Plant Cell Physiol 2007; 48: 252262. http://dx.doi.org/10.1093/pcp/pcl062

[174] Dexter R, Qualley A, Kish CM. Characterization of a petunia acetyltransferase involved in the biosynthesis of the floral volatile isoeugenol. Plant J 2007; 49: 265-275. http://dx.doi.org/10.1111/j.1365-313X.2006.02954.x

[175] Wróbel-Kwiatkowska M, Starzycki M, Zebrowski J, Oszmiański J, Szopa J. Lignin deficiency in transgenic flax resulted in plants with improved mechanical properties. J Biotechnol 2007; 128: 919-934.

http://dx.doi.org/10.1016/j.jbiotec.2006.12.030

[176] Katsumoto $Y$, Fukuchi-Mizutani M, Fukui $Y$ et al. Engineering of the Rose Flavonoid Biosynthetic Pathway Successfully Generated Blue-Hued Flowers Accumulating Delphinidin. Plant Cell Physiol 2007; 48(11): 1589-1600. http://dx.doi.org/10.1093/pcp/pcm131

[177] Xiao D, Singh SV. z-Guggulsterone, a constituent of Ayurvedic medicinal plant Commiphora mukul, inhibits angiogenesis in vitro and in vivo. Mol Cancer Ther 2008; 7(1): 171-180.

http://dx.doi.org/10.1158/1535-7163.MCT-07-0491

[178] Song J, Wang Z. RNAi-mediated suppression of the phenyl anine ammonia-lyase gene in Salvia miltiorrhiza causes abnormal phenotypes and a reduction in rosmarinic acid biosynthesis. J Plant Res 2011; 124:183-192. http://dx.doi.org/10.1007/s10265-010-0350-5

[179] Lin X, Xiao M, Luo Y, Wang J, Wang $\mathrm{H}$. The effect of RNAiinduced silencing of FaDFR on anthocyanin metabolism in strawberry (Fragaria x ananassa) fruit. Sci Hort 2013; 160: 123-128.

http://dx.doi.org/10.1016/j.scienta.2013.05.024 
[180] Sharafi A, Sohi HH, Mousavi A. Metabolic engineering of morphinan alkaloids by over-expression of codeinone reductase in transgenic hairy roots of Papaver bracteatum, the Iranian poppy. Biotechnol Lett 2013; 35: 445-453. http://dx.doi.org/10.1007/s10529-012-1080-7

[181] Cankar K, Jongedijk E, Klompmaker M. (+)-Valencene production in Nicotiana benthamiana is increased by down regulation of competing pathways. Biotechnol J 2015; 10(1): 180-189.

http://dx.doi.org/10.1002/biot.201400288

[182] Schena M, Shalon D, Davis RW, Brown PO. Quantitative monitoring of gene expression pattern with a complementary DNA microarray. Science 1995; 270: 467-470. http://dx.doi.org/10.1126/science.270.5235.467

[183] Siahsar B, Rahimi M, Tavassoli A, Raissi AS. Application of Biotechnology in Production of Medicinal Plants. AmEurasian J Agric Environ Sci 2011; 11 (3): 439-444.

[184] Christen Y, Olano-Martin E, Packer L. Egb761 in the postgenomics era: New tools from molecular biology for the study of complex products such as Ginkgo biloba extract. Cell Mol Bio 2002; 48: 593-599.

[185] Lizuka N, Masaaki O, Yamamoto $\mathrm{K}$ et al. Identification of common or distinct genes related to Anti-tumour activities of a medicinal herb and its major component by oligonucleotide microarray. Int J Cancer 2003; 107: 666-672. http://dx.doi.org/10.1002/ijc.11452

[186] Tsoi PY, Wu HS, Wong MS, Chen SI, Fong WF. Genotyping and species identification of Fritillaria by DNA chip technology. Acta Pharm Sin 2003; 4: 185-190.

[187] Khan MY, Aliabbas S, Kumar V, Rajkumar S. Recent advances in medicinal plant biotechnology. Indian $\mathrm{J}$ Biotechnol 2009; 8: 9-22.

[188] Lee $\mathrm{MH}$, Jeong $\mathrm{JH}$, Seo JW et al. Enhanced triterpene and phytosterol biosynthesis in Panax ginseng overexpressing squalene synthase gene. Plant Cell Physiol 2004; 45(8): 976984.

http://dx.doi.org/10.1093/pcp/pch126

[189] Niggeweg R, Michael AJ, Martin C. Engineering plants with increased levels of the antioxidant chlorogenic acid. Nat Biotechnol 2004; 22 (6): 746-754. http://dx.doi.org/10.1038/nbt966

[190] Ogita S, Uefuji H, Yamaguchi Y, Koizumi N, Sano H. RNA interference: Producing decaffeinated coffee plants. Nature 2003; 423: 823. http://dx.doi.org/10.1038/423823a

[191] Breyne P, Zabeau M. Genome-wide expression analysis of plant cell cycle modulated genes. Curr Opin Plant Biol 2001; 4: $136-142$. http://dx.doi.org/10.1016/S1369-5266(00)00149-7

[192] Breyne P, Dreesen R, Cannoot B et al. Quantitative cDNAAFLP analysis for genome-wide expression studies. Mol Genet Genomics 2003; 269: 173-179.

[193] Goossens A, Häkkinen ST, Laakso I et al. A functional genomics approach toward the understanding of secondary metabolism in plant cells. PNAS 2003; 100: 8595-8600. http://dx.doi.org/10.1073/pnas. 1032967100

[194] Gantet P, Memelink J. Transcription factors: tools to engineer the production of pharmacologically active plant metabolites. Trends Pharmacol Sci 2002; 23: 563-569. http://dx.doi.org/10.1016/S0165-6147(02)02098-9

[195] Doran PM. Foreign protein production in plant tissue cultures. Curr Opin Biotechnol 2000; 11: 199-204. http://dx.doi.org/10.1016/S0958-1669(00)00086-0

[196] Sato F, Hashimoto T, Hachiya A, et al. Metabolic engineering of plant alkaloid biosynthesis. Proc Natl Acad Sci USA 2001; 98(1): 367-72.

http://dx.doi.org/10.1073/pnas.98.1.367

DOI: http://dx.doi.org/10.6000/1927-3037.2016.05.03.4

(C) 2016 Tripathi et al.; Licensee Lifescience Global.

This is an open access article licensed under the terms of the Creative Commons Attribution Non-Commercial License (http://creativecommons.org/licenses/by-nc/3.0/) which permits unrestricted, non-commercial use, distribution and reproduction in any medium, provided the work is properly cited. 